\title{
Composite Materials based on Light Elements for Hydrogen Storage
}

\author{
Takayuki Ichikawa ${ }^{1}$, Nobuko Hanada ${ }^{2}$, Shigehito Isobe ${ }^{2}$, Haiyan Leng ${ }^{2}$ and Hironobu Fujii ${ }^{1}$ \\ ${ }^{1}$ Materials Science Center, N-BARD, Hiroshima University, Higashi-Hiroshima 739-8526, Japan \\ ${ }^{2}$ Graduate School of Advanced Sciences of Matter, Hiroshima University, Higashi-Hiroshima 739-8530, Japan
}

In this paper, we review our recent experimental results on hydrogen storage properties of light elements $\mathrm{Li}, \mathrm{C}$ and $\mathrm{Mg}$ based nanocomposite materials. The results are summarized as follows: In the Li-N-H system, such as the ball milled 1:1 mixture of Li amide and Li hydride containing a small amount of $\mathrm{TiCl}_{3}(1 \mathrm{~mol} \%)$, a large amount of hydrogen $(\sim 6$ mass $\%)$ is absorbed and desorbed in the temperature range from 150 to $250^{\circ} \mathrm{C}$ with good reversibility and high reaction rate. Furthermore, in the ball milled mixture of $3 \mathrm{Mg}\left(\mathrm{NH}_{2}\right)_{2}$ and $8 \mathrm{LiH}$, $\sim 7$ mass $\%$ of hydrogen is reversibly stored in the temperature from 140 to $220^{\circ} \mathrm{C}$, indicating one of the suitable hydrogen storage materials. In graphite containing a small amount of nanometer sized Fe ( $\sim 2$ at. \%), a large amount of hydrogen ( $\sim 7$ mass $\%)$ is chemisorbed by ball milling for $80 \mathrm{~h}$ under less than $1 \mathrm{MPa}$ of $\mathrm{H}_{2}$-gas pressure. However, the chemisorbed hydrogen capacity decreases with increase in the milling pressure for the $80 \mathrm{~h}$ ball milled graphite (down to $\sim 4.1$ mass $\%$ at $6 \mathrm{MPa}$ ), while the physisorbed hydrogen capacity in graphite increases with increase in the milling pressure, reaching up to $0.5 \sim 1.0$ mass $\%$ at $6 \mathrm{MPa}$. Unfortunately, the desorption temperature of chemisorbed hydrogen is higher than $300^{\circ} \mathrm{C}$. Therefore, some break-through is necessary for the development of carbon-based materials as one of the hydrogen storage systems. On the other hand, some nano-composite $\mathrm{Mg}$ catalyzed by Ni nano-particle or $\mathrm{Nb}$ oxide reveals superior reversible hydrogen storage properties: $\sim 6.5$ mass $\%$ of hydrogen is reversibly stored in the temperature range from 150 to $250^{\circ} \mathrm{C}$. Especially, the $\mathrm{Nb}$ metals uniformly dispersed in nanometer scale on the surface of $\mathrm{MgH}_{2}$, which was produced by reduction of $\mathrm{Nb}_{2} \mathrm{O}_{5}$, is the best catalyst we have studied so far. Thus, it seems that some $\mathrm{Mg}$ nano-composites catalyzed by nano-particles of d-electron transition metals is acceptable for practical applications.

(Received July 21, 2004; Accepted September 28, 2004)

Keywords: hydrogen storage, mechanical ball milling, lithium amide-imide system, metal nitrogen hydrogen system, ammonia, magnesium hydride, nano-structured graphite, catalyst, d-electron transition metal

\section{Introduction}

Protection of the earth from pollution is one of the most important issues to be solved by the human race. However, the fast growing world population, increasing globalization and emerging nations on the threshold of becoming highly mobile societies will yield more and more atmospheric pollution. Thus, hydrogen energy systems have been proposed as a means to reduce greenhouse gas and other harmful emissions from stationary and mobile sources. In order to realize hydrogen energy systems in the near future, we have to develop energy storage and transportation technologies. One of the key technologies we need to develop is a high performance hydrogen storage (H-storage) tank, especially, which is to be used in fuel-cell electric vehicles (FCEV). Containers of liquid hydrogen, high-pressure gas hydrogen, and absorbed hydrogen in chemical or metal hydrides with light elements in the periodic table are being investigated all over the world. ${ }^{1-5)}$ These methods have advantages and disadvantages, but the method chosen will have to be compact, light, safe and affordable as on-board storage.

Condensation into liquid is particularly attractive from the viewpoint of the energy density. However, the condensation temperature of hydrogen at $0.1 \mathrm{MPa}$ is $-253^{\circ} \mathrm{C}$ and heat transfer through the container leads directly to the loss of hydrogen. Larger containers have a smaller surface to volume ratio than small ones, so that the loss of hydrogen due to evaporation is smaller. Therefore, it is useful for a tanker, truck or bus with huge liquid hydrogen containers, but unsuitable as a hydrogen container for the compact FCEV.

In most countries, classical high-pressure tanks made of cheap steel are regularly filled up to 15 or $20 \mathrm{MPa}$. In order to run a compact FCEV for $400 \mathrm{~km}$, it needs a tank that can store $4 \mathrm{~kg}$ of hydrogen. This means that, an internal volume of
0.225 liters is required, but this is too large a volume for a compact car. Recently, novel high-pressure tanks made of carbon-fiber-reinforced composite materials are being developed; these are tested up to $60 \mathrm{MPa}$ and filled up to $35 \mathrm{MPa}$ for regular use. The novel high-pressure tanks would contain about $\sim 4 \mathrm{~kg}$ hydrogen by weight, but still has the disadvantage that the fuel tank would be too large by volume for a compact FCEV. In order to overcome this disadvantage, a very-high-pressure tank of up to $70 \mathrm{MPa}$ has been considered for FCEV. However, there is considerable risk in using veryhigh-pressure vessels. The compression itself is the most dangerous and complicated part. There are still problems remaining that need to be solved for high-pressure containers.

It is well known that metal hydride systems can store more hydrogen in a safe and efficient way than liquid hydrogen or high-pressure hydrogen. However, materials with good storage capabilities and reversibility only desorb hydrogen at relatively high temperatures, which are too high for fuel cell application, while materials fitting these requirements are too heavy or too expensive for commercial application.

In these situations, $\mathrm{H}$-storage research projects have been initiated all over the world. In 2003 in Japan, the New Energy and Industrial Technology Development Organization (NEDO) has set a target to develop reversible H-storage media capable of delivering 5.5 mass $\% \mathrm{H}$ at less than $150^{\circ} \mathrm{C}$ as a research and development program on $\mathrm{H}$-storage materials. In USA, the Department of Energy (DOE) has set a target to develop and verify on-board H-storage systems achieving $2 \mathrm{kWh} / \mathrm{kg}\left(6\right.$ mass \%) at less than $100^{\circ} \mathrm{C}$ by 2010 . Internationally, the International Energy Agency (IEA) has set a target to achieve a reversible $\mathrm{H}$-storage medium with 5 mass $\% \mathrm{H}_{2}$ recoverable at $T<80^{\circ} \mathrm{C}$. In recent years, in order to achieve the above targets, new materials with lighter elements, such as lithium (Li), sodium $(\mathrm{Na})$, carbon $(\mathrm{C})$ or 
magnesium (Mg) based materials, have been developed to overcome the disadvantage of heavy weight in conventional metal hydrides.

In this paper, we review our recent experimental results on the $\mathrm{H}$-storage properties of light elements $\mathrm{Li}, \mathrm{C}$ and $\mathrm{Mg}$ based nano-composite materials, which were designed by a mechano-chemical method.

\section{Hydrogen Storage Properties of Lithium Based Materials}

To overcome the disadvantage of too heavy weight of conventional metal hydrides for H-storage, some chemical hydrides composed of light elements such as $\mathrm{Li}$ and $\mathrm{Na}$ have been attracted as new H-storage materials in these days. In particular, the $\mathrm{H}$-storage properties of some alanate systems have been studied by many researchers till now, ${ }^{6-34)}$ in which hydrogen is desorbed by the following 2-step reactions:

$$
\begin{aligned}
& \mathrm{MAlH}_{4} \rightarrow 1 / 3 \mathrm{M}_{3} \mathrm{AlH}_{6}+2 / 3 \mathrm{Al}+\mathrm{H}_{2} \\
& 1 / 3 \mathrm{M}_{3} \mathrm{AlH}_{6} \rightarrow \mathrm{MH}+1 / 3 \mathrm{Al}+1 / 2 \mathrm{H}_{2} .
\end{aligned}
$$

Here, the total hydrogen capacities for $\mathrm{M}=\mathrm{Na}$ and $\mathrm{Li}$ are theoretically calculated to be 5.6 and 8.0 mass $\%$, respectively. Both the enthalpy changes of the reactions (1) and (2) for $\mathrm{M}=\mathrm{Na}$ were estimated to be endothermic and the reversibility of both the reactions were experimentally confirmed. Then, some catalysts containing $\mathrm{Ti}$ or Zr-elements were doped to improve the reaction rate. On the other hand, the enthalpy changes of the reactions (1) and (2) for $\mathrm{M}=\mathrm{Li}$ have been estimated to be respectively exothermic and endothermic by DTA measurements. Therefore, only the second reaction (2) for $\mathrm{M}=\mathrm{Li}$ should be reversible for $\mathrm{H}$-storage. However, the hydrogenating reaction could not be confirmed so far, because the reaction rate might be too slow for realizing the hydrogenating reaction under moderate temperature and $\mathrm{H}_{2}$ gas pressure.

Concerning with chemical hydrides composed of lithium and boron, many data have been also accumulated. The lithium tetrahydroborate $\left(\mathrm{LiBH}_{4}\right)$ was first synthesized in $1940^{35)}$ by the reaction of the ethyl lithium with diborane $\left(\mathrm{B}_{2} \mathrm{H}_{6}\right)$. Until now, direct synthesis from $\mathrm{Li}$ or $\mathrm{LiH}, \mathrm{B}$ and $\mathrm{H}_{2}$ at elevated conditions up to $650^{\circ} \mathrm{C}$ and $15 \mathrm{MPa}$ of $\mathrm{H}_{2}$ pressure has been tried by many researchers, but all the attempts failed. Quite recently, Orimo et al. have succeeded to synthesize $\mathrm{LiBH}_{4}$ from $\mathrm{LiH}$ and $\mathrm{B}$ at $500^{\circ} \mathrm{C}$ and under $35 \mathrm{MPa}$ of $\mathrm{H}_{2}$ gas pressure. ${ }^{36)}$ On the other hand, the hydrogen desorption (HD) process from $\mathrm{LiBH}_{4}$ was examined by Fedneva et al. in 1964. ${ }^{37)}$ Three endothermic reactions at $\sim 110, \sim 280$ and $\sim 480^{\circ} \mathrm{C}$ were observed in the TDS spectra. The first peak corresponds to polymorphic transformation, the second one to the fusion of $\mathrm{LiBH}_{4}$ and the third one starts at $380^{\circ} \mathrm{C}$ and liberates $80 \%$ of the hydrogen in $\mathrm{LiBH}_{4}$. Recently, Züttel et al. showed that a slight amount of hydrogen was desorbed during the structural transformation around $100^{\circ} \mathrm{C}$ and major hydrogen desorption of 13.5 mass $\%$ started at $\sim 200^{\circ} \mathrm{C}$ when the $\mathrm{SiO}_{2}$-powder was added to the $\mathrm{LiBH}_{4} \cdot{ }^{38)}$

On the Li-N-H systems, there have been new developments for $\mathrm{H}$-storage in recent years. We have also started to study their H-storage properties in ball milled mixture of metal hydrides and amides prepared by a mechano-chemical method. About our recent development on Li-N-H systems for $\mathrm{H}$-storage, we will review in the following session.

\subsection{Novel reaction of $\mathrm{LiNH}_{2}$ and $\mathrm{LiH}$ for hydrogen storage}

As early as 1910, Dafert and Miklauz ${ }^{39)}$ had reported that the reaction between $\mathrm{Li}_{3} \mathrm{~N}$ and $\mathrm{H}_{2}$ proceeded at $200-300^{\circ} \mathrm{C}$ and generated $\mathrm{Li}_{3} \mathrm{NH}_{4}$. However, the product was proved to be a mixture of lithium amide and lithium hydride by Ruff and Goerges ${ }^{40)}$ as follows;

$$
\mathrm{Li}_{3} \mathrm{~N}+2 \mathrm{H}_{2} \rightarrow \mathrm{LiNH}_{2}+2 \mathrm{LiH} .
$$

Furthermore, they had claimed that the mixture was decomposed into lithium imide and released $\mathrm{H}_{2}$ on heating as follows;

$$
\mathrm{LiNH}_{2}+2 \mathrm{LiH} \rightarrow \mathrm{Li}_{2} \mathrm{NH}+\mathrm{LiH}+\mathrm{H}_{2} .
$$

These were the first reports concerning hydrogen absorption and desorption reactions on Li-N-H systems. After that, there had been no researches on $\mathrm{H}$-storage properties in $\mathrm{Li}-\mathrm{N}-\mathrm{H}$ systems for almost one century.

In recent years, Chen et al. ${ }^{41)}$ and $\mathrm{Hu}$ and Ruckenstein ${ }^{42)}$ demonstrated that $\mathrm{Li}_{3} \mathrm{~N}$ reversibly absorbed and desorbed hydrogen by the following 2-step reactions at relatively low temperatures under moderate pressures;

$$
\mathrm{Li}_{3} \mathrm{~N}+2 \mathrm{H}_{2} \leftrightarrow \mathrm{Li}_{2} \mathrm{NH}+\mathrm{LiH}+\mathrm{H}_{2} \leftrightarrow \mathrm{LiNH}_{2}+2 \mathrm{LiH} .
$$

They reported that a high capacity of hydrogen $(\sim 9.4$ mass\%) was reversibly stored in the above system. Since that, some alkali and alkali earth metal nitrides or their imides have become one of the promising families for H-storage media. ${ }^{41-48)}$

The enthalpy change of the first step of the reaction (5) could be estimated to be $148 \mathrm{~kJ} / \mathrm{mol} \mathrm{H} \mathrm{H}_{2}$ and that of the second step to be $45 \mathrm{~kJ} / \mathrm{mol} \mathrm{H}_{2}{ }^{41)}$ Since the second reaction has a much smaller enthalpy change for hydrogen release than the first one and has a potential for storing still a large amount of hydrogen (6.5 mass\%), we focused on the second step of the reaction (5), which is expressed as follows;

$$
\mathrm{LiNH}_{2}+\mathrm{LiH} \leftrightarrow \mathrm{Li}_{2} \mathrm{NH}+\mathrm{H}_{2} .
$$

In the above reaction, we could commercially buy both of $\mathrm{LiNH}_{2}$ and $\mathrm{LiH}$ except $\mathrm{Li}_{2} \mathrm{NH}$.

So, first of all, we started to study HD properties from the 1:1 mixture of purchased $\mathrm{LiNH}_{2}$ and $\mathrm{LiH}^{4}{ }^{46}$ To achieve a good contact between $\mathrm{LiNH}_{2}$ and $\mathrm{LiH}$ in nanometer scale, the mixture was ball-milled by a planetary mill equipment (Fritsch P7) under a $\mathrm{H}_{2}$-gas atmosphere of $1 \mathrm{MPa}$ for $2 \mathrm{~h}$. A profile of thermal desorption mass spectroscopy (TDMS) for the ball milled mixture are shown in Fig. 1. We notice that the $\mathrm{NH}_{3}$ gas in addition to hydrogen gas is desorbed from the ball milled mixture at higher temperature region around $350^{\circ} \mathrm{C}$, where the hydrogen desorption synchronizes with the $\mathrm{NH}_{3}$ desorption. Usually, it is known that the $\mathrm{NH}_{3}$ gas is emitted by the following decomposition reaction on heating process;

$$
2 \mathrm{LiNH}_{2} \rightarrow \mathrm{Li}_{2} \mathrm{NH}+\mathrm{NH}_{3} .
$$

Here the enthalpy change for releasing $\mathrm{NH}_{3}$ is endothermic 


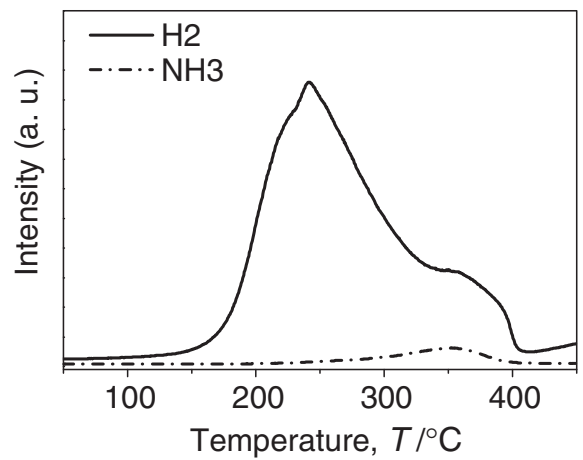

Fig. 1 TDMS profiles for $\mathrm{H}_{2}$ and $\mathrm{NH}_{3}$ gases from the mixture of $\mathrm{LiNH}_{2}$ and $\mathrm{LiH}$ in the $1: 1$ mole ratio prepared by mechanically milling under $1 \mathrm{MPa}_{2}$ atmosphere for $2 \mathrm{~h}$.

and is estimated to be $84 \mathrm{~kJ} / \mathrm{mol} \mathrm{NH}$. Therefore, the $\mathrm{NH}_{3}$ emission from the mixture at higher temperatures might be due to thermal decomposition of remaining $\mathrm{LiNH}_{2}$ that could not react with $\mathrm{LiH}$ because of slow reaction speed between $\mathrm{LiNH}_{2}$ and $\mathrm{LiH}$.

Then, in order to improve the reaction rate, we examined the catalytic effect on the HD properties in the ball milled 1:1 mixture of $\mathrm{LiNH}_{2}$ and $\mathrm{LiH}^{46)}$ A small amount (1 at\%) of $\mathrm{Fe}$, $\mathrm{Co}$, or $\mathrm{Ni}$ metal with several nanometers diameter, and the chloride of $\mathrm{VCl}_{3}$ or $\mathrm{TiCl}_{3}(1 \mathrm{~mol} \%)$ was added to the $1: 1$ mixture as a catalyst before ball milling and then ball milled for $2 \mathrm{~h}$ under $1 \mathrm{MPa}$ of $\mathrm{H}_{2}$-gas at room temperature. In Fig. 2, the TDMS profiles for $\mathrm{H}_{2}$ and $\mathrm{NH}_{3}$ gases are shown for all the doped mixtures. The mixture containing a small amount of $\mathrm{TiCl}_{3}(1 \mathrm{~mol} \%)$ shows the most superior HD properties among all the doped mixtures; the product shows the sharpest desorption curve and desorbs a large amount of hydrogen (5.5-6.0 mass\%) in the temperature range from 150 to $250^{\circ} \mathrm{C}$ at a heating rate of $5^{\circ} \mathrm{C} / \mathrm{min}$. This indicates that the reaction speed is dramatically improved by doping $1 \mathrm{~mol} \%$ of $\mathrm{TiCl}_{3}$ as a catalyst and the doping leads to lower activation energy for the HD reaction (4) than in the mixture with no catalyst. Here, it is noteworthy that no $\mathrm{NH}_{3}$ gas emission was detected at all in the TDMS measurement up to $450^{\circ} \mathrm{C}$ for the mixture doped $1 \mathrm{~mol} \% \mathrm{TiCl}_{3}$ as a catalyst within our experimental accuracy. This result indicates that all of the $\mathrm{LiNH}_{2}$ were completely consumed by reacting with $\mathrm{LiH}$ until $300^{\circ} \mathrm{C}$ and transformed into $\mathrm{Li}_{2} \mathrm{NH}$ and $\mathrm{H}_{2}$, leading to no $\mathrm{NH}_{3}$ gas emission at all.

Next, we examined the reversibility of the hydrogen desorption and absorption reactions for the ball milled 1:1 mixture with the $1 \mathrm{~mol} \% \mathrm{TiCl}_{3}$ catalysts. ${ }^{46)}$ The reversibility was tested by the following cyclic processes; the hydrogen desorption was performed by keeping the product at $220^{\circ} \mathrm{C}$ for $12 \mathrm{~h}$ under high-vacuum and then the hydrogen absorption was done under pure hydrogen gas up to $3 \mathrm{MPa}$. In Fig. 3, are shown the TDMS profiles after several cycles. The amount of desorbed hydrogen slightly decreases after 2nd cycle, suggesting that a small amount of stable compounds like $\mathrm{Li}_{2} \mathrm{O}$, TiN or $\mathrm{LiCl}$ has been produced during the first heating process. However, since the effective hydrogen capacity was still higher than 5 mass\% after the initial dehydrogenation reaction and the reaction rate did not change after 2 nd cycle

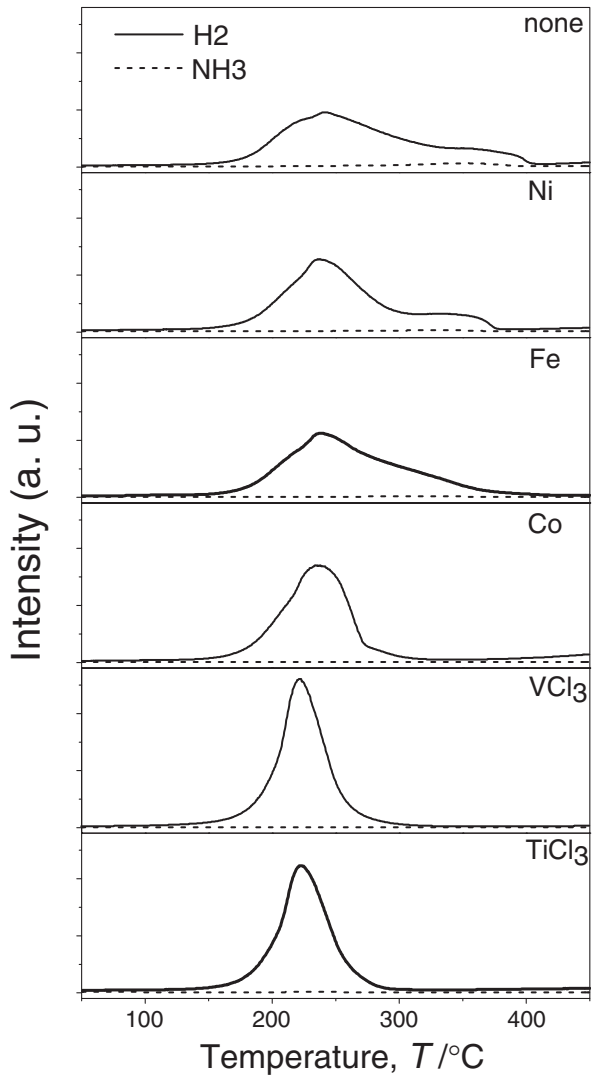

Fig. 2 TDMS profiles for $\mathrm{H}_{2}$ and $\mathrm{NH}_{3}$ gases from the ball milled 1:1 mixture of $\mathrm{LiNH}_{2}$ and $\mathrm{LiH}$ with $1 \mathrm{~mol} \%$ of catalysts $\left(\mathrm{Ni}^{\text {nano }}, \mathrm{Fe}^{\text {nano }}, \mathrm{Co}^{\text {nano }}\right.$, $\mathrm{VCl}_{3}$ and $\mathrm{TiCl}_{3}$ ) by mechanically milling under $1 \mathrm{MPa} \mathrm{H}_{2}$ atmosphere for $2 \mathrm{~h}$.

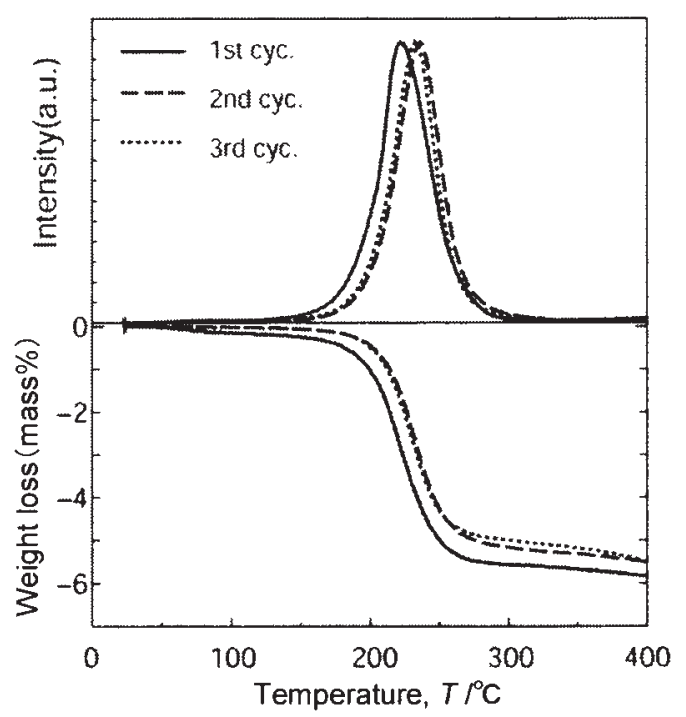

Fig. $3 \mathrm{H}_{2}$ desorption spectra from 1:1 mixture of $\mathrm{LiNH}_{2}$ and $\mathrm{LiH}$ with $1 \mathrm{~mol} \% \mathrm{TiCl}_{3}$ catalyst prepared by mechanically milling under $\mathrm{H}_{2}$ atmosphere for $2 \mathrm{hrs}$ and corresponding weight loss. The solid, dotted and dashed lines correspond to the first, second and third cycles, respectively.

until 10th cycle (almost same as 3rd cycles data), we conclude that the cycle retention is excellent. ${ }^{46)}$

Furthermore, we investigated the kinetics of the HD reaction. Figure 4 shows the logarithmic plot of the residual 


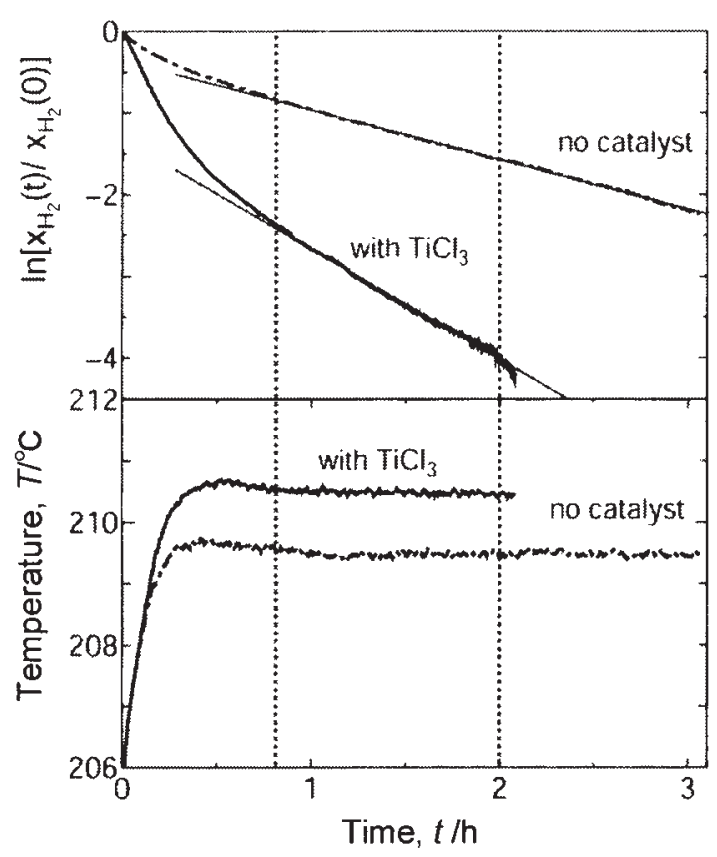

Fig. 4 Logarithmic plots of normalized remaining hydrogen amount, $X_{\mathrm{H}_{2}}(t) / X_{\mathrm{H}_{2}}(t)$, and linear plots of measuring temperature as a function of time for the $1: 1$ ball milled powders with and without 1 mass $\% \mathrm{TiCl}_{3}$ catalyst.

hydrogen content ratio $X_{\mathrm{H}_{2}}(t) / X_{\mathrm{H}_{2}}(0)$ as a function of time for the desorption process from the ball milled 1:1 mixtures with and without $1 \mathrm{~mol} \% \mathrm{TiCl}_{3}$ catalyst. Here, $X_{\mathrm{H}_{2}}(t) / X_{\mathrm{H}_{2}}(0)$ was determined by the thermo-gravimetric analysis (TGA), which were performed under no partial pressure of hydrogen and $\mathrm{NH}_{3}$ using $\mathrm{He}$ gas as a flow gas. In this figure, the temperature fluctuations from a programming temperature are also plotted as a function of time. We notice that the reaction rate of the product with $1 \mathrm{~mol} \% \mathrm{TiCl}_{3}$ as a catalyst is much faster than that without catalyst and almost $90 \%$ of hydrogen is desorbed within $20 \mathrm{~min}$ from the catalyzed mixture at $210^{\circ} \mathrm{C}$. In addition, one can see that both the logarithmic plots are linear against time after measuring temperatures reached at the programming ones, indicating that both the HD reactions are of first order. ${ }^{46)}$

As is described above, it was clarified that the HD reaction is of first order and very fast, although it is considered to be solid-solid reaction. In order to make clear the origin of such unusual reaction behaviors, we examined the TDMS profiles of $\mathrm{NH}_{3}$ and hydrogen gaseous emissions from a singlelayered sample of ball milled $\mathrm{LiNH}_{2}$ and a two-layered sample composed of ball milled $\mathrm{LiNH}_{2}$ and $\mathrm{LiH},{ }^{47)}$ where the ball milled $\mathrm{LiH}$ layer is placed on the ball milled $\mathrm{LiNH}_{2}$ layer as schematically shown in Fig. 5. The detected TDMS profiles for hydrogen and the $\mathrm{NH}_{3}$ gases are shown in Fig. 6 for single-layered $\mathrm{LiNH}_{2}$ with a $1 \mathrm{~mol} \% \mathrm{TiCl}_{3}$ catalyst (A) and without any catalyst (B), and two-layered samples with the $\mathrm{TiCl}_{3}$ catalyst (C) and without any catalyst (D) as well. We can see that the emission of $\mathrm{NH}_{3}$ from $\mathrm{LiNH}_{2}$ itself starts from $\sim 220^{\circ} \mathrm{C}$, and takes a broad peak at $330^{\circ} \mathrm{C}$, while the desorption of $\mathrm{H}_{2}$ from the two-layered sample synchronizes with $\mathrm{NH}_{3}$ emission from $\mathrm{LiNH}_{2}$, irrespective of doping a $1 \mathrm{~mol} \% \mathrm{TiCl}_{3}$. This indicates that $\mathrm{NH}_{3}$ emitted from $\mathrm{LiNH}_{2}$ immediately reacts with $\mathrm{LiH}$ and releases $\mathrm{H}_{2}$. That is, either

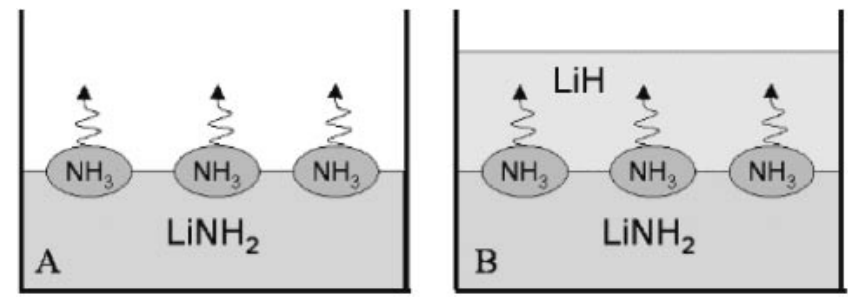

Fig. 5 Schematic figure for sample arrangements of (i) an alone $\mathrm{LiNH}_{2}$ and (ii) a two-layered sample with $\mathrm{LiH}$ on $\mathrm{LiNH}_{2}$ used for TDMS analysis, and both were put in the sample pan. Here, ammonia is emitted by decomposition of $\mathrm{LiNH}_{2}$ to $\mathrm{Li}_{2} \mathrm{NH}$.

the reaction,

$$
\mathrm{LiH}+\mathrm{NH}_{3} \rightarrow \mathrm{LiNH}_{2}+\mathrm{H}_{2},
$$

or the reaction,

$$
2 \mathrm{LiH}+\mathrm{NH}_{3} \rightarrow \mathrm{Li}_{2} \mathrm{NH}+2 \mathrm{H}_{2},
$$

would be realized in this experiment. If the reaction (8) is realized, the reaction is calculated to be exothermic $(\sim 42 \mathrm{~kJ} /$ mol) from the literature. Therefore, the reaction (8) should progress in the milling process under $\mathrm{NH}_{3}$-gas atmosphere even at room temperature. Then, we performed ball mill treatment of $\mathrm{LiH}(\sim 40 \mathrm{mg})$ under $\mathrm{NH}_{3}$-gas atmosphere of $0.4 \mathrm{MPa}$ for $2 \mathrm{~h}$, which corresponds to the $1: 1$ molar ratio of $\mathrm{LiH}$ and $\mathrm{NH}_{3}$. The examined X-ray diffraction (XRD) profile indicated that the product is assigned to be a single phased $\mathrm{LiNH}_{2}$ after milling. Thus, we clarified that the reaction (8) is one of the elemental reactions in the HD reaction (6). From the above results, we conclude that the following 2-step elemental reactions mediated by ammonia are essential for the $\mathrm{HD}$ reaction (6):

$$
2 \mathrm{LiNH}_{2} \rightarrow \mathrm{Li}_{2} \mathrm{NH}+\mathrm{NH}_{3}
$$

and

$$
\mathrm{LiH}+\mathrm{NH}_{3} \rightarrow \mathrm{LiNH}_{2}+\mathrm{H}_{2} .
$$

In Fig. 6, we notice two other interesting points to be considered. One is that $\mathrm{H}_{2}$-releasing temperature from the two-layered sample is lower than that of $\mathrm{NH}_{3}$ from the single layered sample. The other is that the doping of $\mathrm{TiCl}_{3}$ in $\mathrm{LiNH}_{2}$ and $\mathrm{LiH}$ gave no strong influence on both of the $\mathrm{NH}_{3}$ and $\mathrm{H}_{2}$ emission processes.

It is of interest to point out that the onset of hydrogen desorption from the $\mathrm{TiCl}_{3}$-doped 1:1 mixture of $\mathrm{LiH}$ and $\mathrm{LiNH}_{2}$ prepared by ball milling method is much lower temperature than that in two-layered sample composed of $\mathrm{LiH}$ and $\mathrm{LiNH}_{2}$ with a small amount of $\mathrm{TiCl}_{3}(1 \mathrm{~mol} \%)$. This indicates that $\mathrm{TiCl}_{3}$ acts as an excellent catalyst on the $\mathrm{H}_{2}$ desorption from the ball milled 1:1 mixture, but not acts as a catalyst on both of the $\mathrm{NH}_{3}$ and $\mathrm{H}_{2}$ emissions in both elemental reactions (7) and (8) themselves. Therefore, it seems likely that the catalyst $\mathrm{TiCl}_{3}$ acts as a role for the transfer of $\mathrm{NH}_{3}$ molecule from $\mathrm{LiNH}_{2}$ to $\mathrm{LiH}$ in nanometer scale. Moreover, the above results suggest that $\mathrm{LiH}$ plays a role of something like a catalyst for the decomposition of $\mathrm{LiNH}_{2}$ in the ball milled mixture, because the HD temperature from the 1:1 mixture is actually much lower than the $\mathrm{NH}_{3}$ emission temperature from $\mathrm{LiNH}_{2}$ itself. A preliminary 


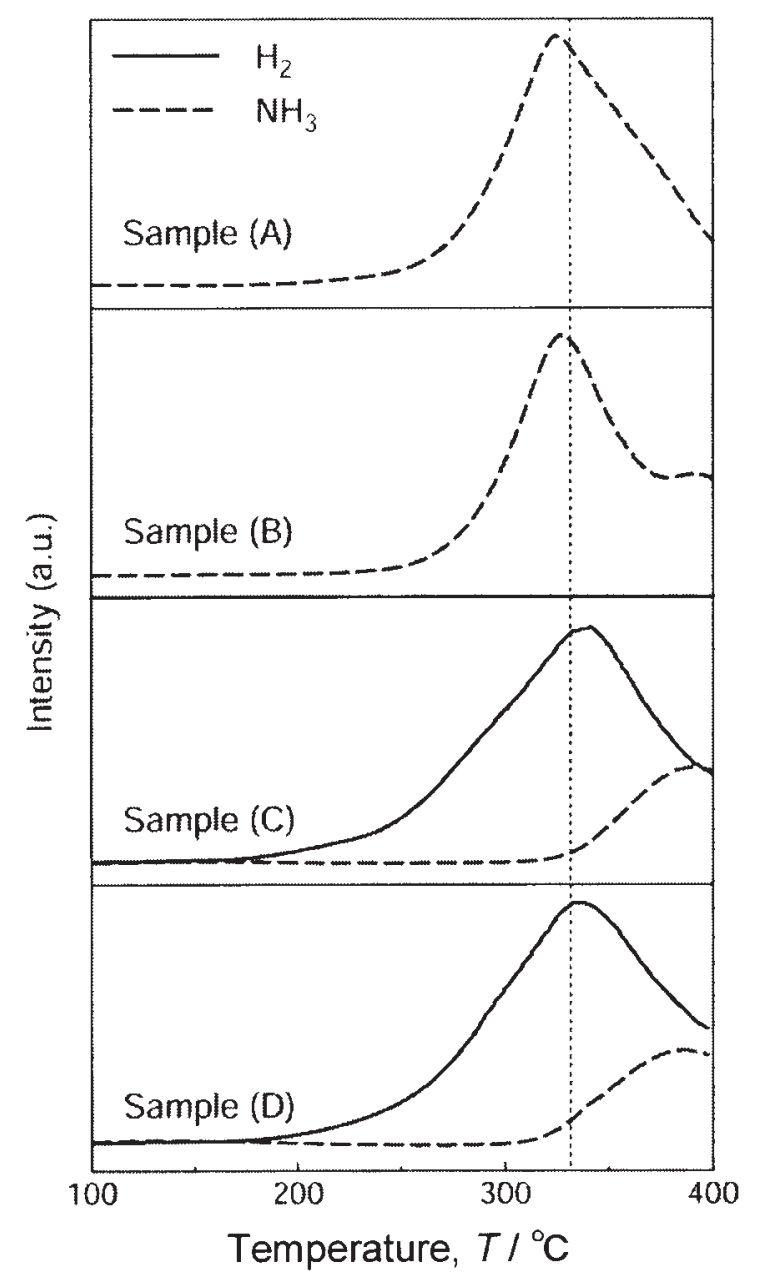

Fig. 6 TDMS profiles for hydrogen and the $\mathrm{NH}_{3}$ gases from single-layered $\mathrm{LiNH}_{2}$ with $1 \mathrm{~mol} \% \mathrm{TiCl}_{3}$ catalyst (A) and without any catalyst (B), and two-layered samples with the $\mathrm{TiCl}_{3}$ catalyst (C) and without any catalyst (D).

Raman scattering experiment for $\mathrm{LiNH}_{2}$ indicated that a quite small amount of $\mathrm{NH}_{3}$ molecule started to be liberated from the $\mathrm{LiNH}_{2}$ particle surface around $70^{\circ} \mathrm{C}$, while the decomposition of $\mathrm{LiNH}_{2}$ into $\mathrm{Li}_{2} \mathrm{NH}$ and $\mathrm{NH}_{3}$ normally started from more than $200^{\circ} \mathrm{C}$.

From the above results, we conclude that the HD reaction (6) is controlled by the two-step gas-solid elemental reactions (7) and (8) mediated by ammonia. Thus, we can understand that the HD reaction (6) is first order and shows the fast reaction rate. Then, the HD reaction in reaction (6) can be expressed as follows;

$$
\begin{aligned}
\mathrm{LiH}+\mathrm{LiNH}_{2} \rightarrow & \frac{1}{2} \mathrm{LiH}+\left(\frac{1}{2} \mathrm{LiH}+\frac{1}{2} \mathrm{NH}_{3}\right)+\frac{1}{2} \mathrm{Li}_{2} \mathrm{NH} \\
\rightarrow & \frac{1}{2} \mathrm{LiH}+\frac{1}{2} \mathrm{LiNH}_{2}+\frac{1}{2} \mathrm{Li}_{2} \mathrm{NH}+\frac{1}{2} \mathrm{H}_{2} \\
\rightarrow & \frac{1}{4} \mathrm{LiH}+\frac{1}{4} \mathrm{LiNH}_{2}+\left(\frac{1}{2}+\frac{1}{4}\right) \\
& \times \mathrm{Li}_{2} \mathrm{NH}+\left(\frac{1}{2}+\frac{1}{4}\right) \mathrm{H}_{2} \\
& \rightarrow \cdots
\end{aligned}
$$

$$
\begin{aligned}
& \rightarrow \frac{1}{2^{n}} \mathrm{LiH}+\frac{1}{2^{n}} \mathrm{LiNH}_{2}+\sum_{k=1}^{n} \frac{1}{2^{k}} \\
& \quad \times \mathrm{Li}_{2} \mathrm{NH}+\sum_{k=1}^{n} \frac{1}{2^{k}} \mathrm{H}_{2} \\
& \rightarrow \mathrm{Li}_{2} \mathrm{NH}+\mathrm{H}_{2} .
\end{aligned}
$$

That is to say: At the first step, $\mathrm{LiNH}_{2}$ decomposes into $\mathrm{Li}_{2} \mathrm{NH} / 2$ and $\mathrm{NH}_{3} / 2$, and then the emitted $\mathrm{NH}_{3} / 2$ quickly reacts with $\mathrm{LiH} / 2$, transforming into $\mathrm{LiNH}_{2} / 2$ and $\mathrm{H}_{2} / 2$. At the second one, the produced $\mathrm{LiNH}_{2} / 2$ decomposes into $\mathrm{Li}_{2} \mathrm{NH} / 4+\mathrm{NH}_{3} / 4$ and then $\mathrm{NH}_{3} / 4+\mathrm{LiH} / 4$ transform to $\mathrm{LiNH}_{2} / 4+\mathrm{H}_{2} / 4$, and such successive steps continue until $\mathrm{LiNH}_{2}$ and $\mathrm{LiH}$ completely transform into $\mathrm{Li}_{2} \mathrm{NH}$ and $\mathrm{H}_{2}$. These successive multi step reaction might progress at low temperature by doping some appropriate catalysts like $\mathrm{TiCl}_{3} \cdot{ }^{47)}$

\subsection{Novel reaction of $\mathrm{Mg}\left(\mathrm{NH}_{2}\right)_{2}$ and $\mathrm{LiH}$ for hydrogen storage}

As discussed in the above section, we clarified that the HD reaction between $\mathrm{LiNH}_{2}$ and $\mathrm{LiH}$ was controlled by the gassolid 2-step elemental reactions mediated by ammonia. Similarly, we can expect that the reaction between magnesium amide $\mathrm{Mg}\left(\mathrm{NH}_{2}\right)_{2}$ and $\mathrm{LiH}$ would also proceed through $\mathrm{NH}_{3}$-mediating gas-solid reactions as well.

Unfortunately, we can not commercially obtain $\mathrm{Mg}\left(\mathrm{NH}_{2}\right)_{2}$ yet. So, we first synthesized $\mathrm{Mg}\left(\mathrm{NH}_{2}\right)_{2}$ by ball milling $\mathrm{MgH}_{2}$ in a gaseous $\mathrm{NH}_{3}$ atmosphere of $0.4 \mathrm{MPa}$ using a rocking mill with a frequency of $10 \mathrm{~Hz}$ for $13 \mathrm{~h}$ at room temperature, according to the following reaction:

$$
\mathrm{MgH}_{2}+2 \mathrm{NH}_{3} \rightarrow \mathrm{Mg}\left(\mathrm{NH}_{2}\right)_{2}+2 \mathrm{H}_{2}
$$

Then, a mixture of $\mathrm{Mg}\left(\mathrm{NH}_{2}\right)_{2}$ and $\mathrm{LiH}$ with a molar ratio of 3:8 was mechanically milled under a hydrogen gas atmosphere of $1 \mathrm{MPa}$ at $400 \mathrm{rpm}$ for $2 \mathrm{~h}$ and the HD properties were examined. The TDMS and TGA profiles of the ball milled mixture without any catalysts are shown in Fig. 7. The results indicate that a large amount of hydrogen ( $\sim 7$ mass $\%)$ start to be desorbed at $140^{\circ} \mathrm{C}$ and the desorption peaks at $190^{\circ} \mathrm{C}$ at a heating rate of $5^{\circ} \mathrm{C} / \mathrm{min}$ almost without emitting $\mathrm{NH}_{3}$. Here, it is noteworthy that the HD properties of the ball milled mixture of $3 \mathrm{Mg}\left(\mathrm{NH}_{2}\right)_{2}$ and $8 \mathrm{LiH}$ are much better than those of $\mathrm{LiNH}_{2}$ and $\mathrm{LiH}^{2-43)}$ from the viewpoint of both the hydrogen capacity and the desorption temperature. The reason may be due to the fact that $\mathrm{Mg}\left(\mathrm{NH}_{2}\right)_{2}$ is less stable and more easily decomposes into the corresponding imide and nitride than $\mathrm{LiNH}_{2}$ because of the smaller enthalpy change or larger entropy change in the dehydrogenation reaction.

The XRD profile of the mixture after releasing hydrogen at $400^{\circ} \mathrm{C}$ is shown in Fig. 8(a). This shows that the product is the mixed phases of $\mathrm{Li}_{2} \mathrm{NH}$ and $\mathrm{Mg}_{3} \mathrm{~N}_{2}$. Therefore, the HD reaction from the ball milled mixture of $3 \mathrm{Mg}\left(\mathrm{NH}_{2}\right)_{2}$ and $8 \mathrm{LiH}$ can be expressed by the following chemical formula;

$$
3 \mathrm{Mg}\left(\mathrm{NH}_{2}\right)_{2}+8 \mathrm{LiH} \rightarrow \mathrm{Mg}_{3} \mathrm{~N}_{2}+4 \mathrm{Li}_{2} \mathrm{NH}+8 \mathrm{H}_{2} .
$$

From the reaction (12), we can theoretically calculate the amount of $\mathrm{H}$-storage capacity to be $\sim 7$ mass $\%$, which is in good agreement with the experimental amount of desorbed 


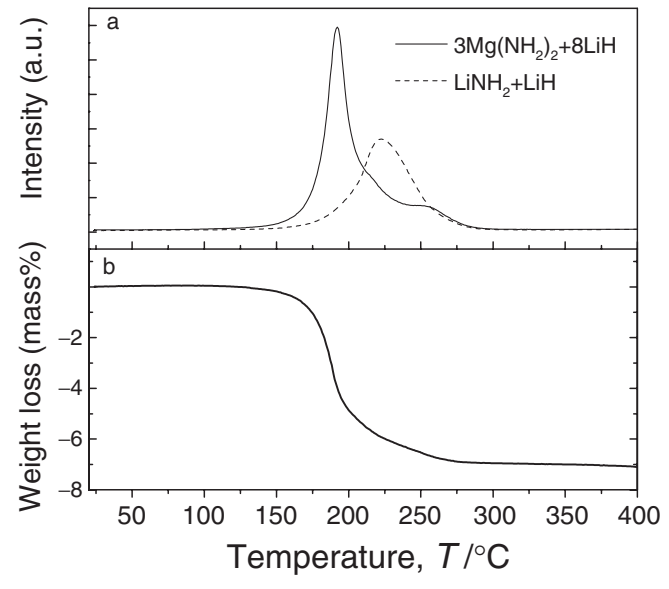

Fig. 7 (a) Hydrogen desorption mass spectrum and (b) weight loss percent due to thermal gravimetry analysis for the mixture of $3 \mathrm{Mg}\left(\mathrm{NH}_{2}\right)_{2}$ and $8 \mathrm{LiH}$ in the heating process up to $400^{\circ} \mathrm{C}$ under a helium flow at a $5^{\circ} \mathrm{C} / \mathrm{min}$ heat rate. Here, the hydrogen desorption mass spectrum for the 1:1 mixture of $\mathrm{LiNH}_{2}$ and $\mathrm{LiH}$ with a small amount $(1 \mathrm{~mol} \%)$ of $\mathrm{TiCl}_{3},{ }^{13)}$ is also shown by dotted line.

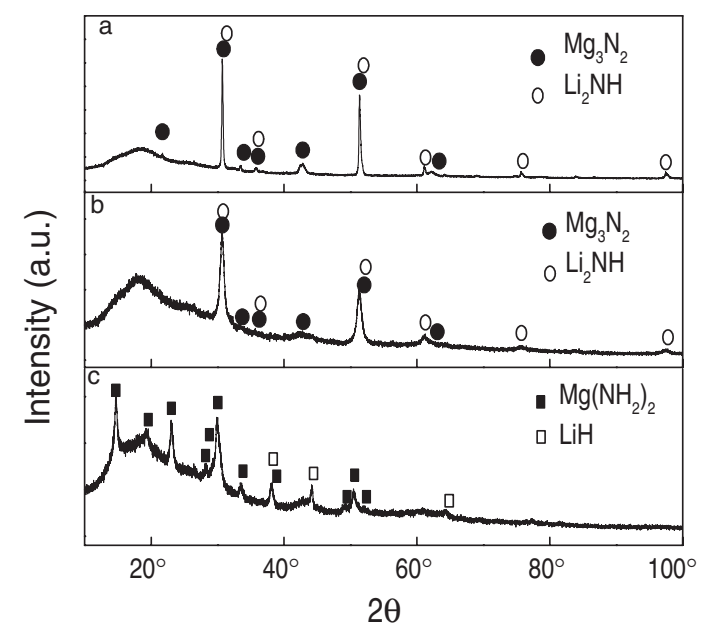

Fig. 8 XRD patterns of $\mathrm{Mg}\left(\mathrm{NH}_{2}\right)_{2}$ (a) after heat treatment at $300^{\circ} \mathrm{C}$ under ammonia atmosphere for $1 \mathrm{~h}$; (b) after thermal desorption under a helium flow at $320^{\circ} \mathrm{C}$ for $2 \mathrm{~h}$ (c) after thermal desorption under a helium flow up to $500^{\circ} \mathrm{C}$ at a heating rate of $5^{\circ} \mathrm{C} / \mathrm{min}$. The broad peak around $20^{\circ}$ is due to grease using for fixing the powder on the sample holder.

\section{hydrogen.}

Next, we examined the reversibility of the reaction (12) by following procedure. First, the milled mixture of $3 \mathrm{Mg}\left(\mathrm{NH}_{2}\right)_{2}$ and $8 \mathrm{LiH}$ is dehydrogenated in vacuum at $170^{\circ} \mathrm{C}$ for $8 \mathrm{~h}$. Secondly, the mixture is hydrogenated by slow cooling in the furnace after keeping it at $200^{\circ} \mathrm{C}$ under a $\mathrm{H}_{2}$ pressure of $3 \mathrm{MPa}$ for $8 \mathrm{~h}$. As shown in Fig. 8(b), the profile indicates that the dehydrogenating reaction from $3 \mathrm{Mg}\left(\mathrm{NH}_{2}\right)_{2}$ and $8 \mathrm{LiH}$ to $\mathrm{Mg}_{3} \mathrm{~N}_{2}$ and $4 \mathrm{Li}_{2} \mathrm{NH}$ proceeds even at $170^{\circ} \mathrm{C}$ in vacuum. After the re-hydrogenating treatment, the product is again transformed into the original mixture of $3 \mathrm{Mg}\left(\mathrm{NH}_{2}\right)_{2}$ and 8LiH (see Fig. 8(c)). Thus, we conclude that the chemical reaction (12) is completely reversible.

Similar to the progress of the HD reaction between $\mathrm{LiNH}_{2}$ and $\mathrm{LiH},{ }^{47)}$ the dehydrogenation reaction from the mixture of $3 \mathrm{Mg}\left(\mathrm{NH}_{2}\right)_{2}$ and $8 \mathrm{LiH}$ should proceed by the following three kinds of elementary reactions: (i) The first one is that $3 \mathrm{Mg}\left(\mathrm{NH}_{2}\right)_{2}$ decomposes to $3 \mathrm{MgNH}$ and $3 \mathrm{NH}_{3}$, and then $3 \mathrm{MgNH}$ continues to decompose to $\mathrm{Mg}_{3} \mathrm{~N}_{2}$ and $\mathrm{NH}_{3}$ at relatively higher temperatures; (ii) the second one is that the emitting $4 \mathrm{NH}_{3}$ reacts with $4 \mathrm{LiH}$ and transforms into $4 \mathrm{LiNH}_{2}$ and $4 \mathrm{H}_{2}$; (iii) the third one is that $4 \mathrm{LiNH}_{2}$ decomposes to $2 \mathrm{Li}_{2} \mathrm{NH}$ and $2 \mathrm{NH}_{3}$. Continuously, $2 \mathrm{NH}_{3}$ again reacts with remaining $2 \mathrm{LiH}$, transforming into $2 \mathrm{LiNH}_{2}$ and $2 \mathrm{H}_{2}$ and then $2 \mathrm{LiNH}_{2}$ decomposes to $\mathrm{Li}_{2} \mathrm{NH}$ and $\mathrm{NH}_{3}$, and such successive steps continue until $4 \mathrm{LiNH}_{2}$ and $4 \mathrm{LiH}$ completely transform into $4 \mathrm{Li}_{2} \mathrm{NH}$ and $4 \mathrm{H}_{2}$. It seems that these successive reactions might proceed even at lower temperature through the close contact between $\mathrm{Mg}\left(\mathrm{NH}_{2}\right)_{2}$ and $\mathrm{LiH}$ in a nano-scale by milling treatment.

On the other hand, the hydrogenation reaction process in the reaction (12) can not be simply understood. This is because that pure $\mathrm{Li}_{2} \mathrm{NH}$ is hydrogenated into $\mathrm{LiH}$ and $\mathrm{LiNH}_{2},{ }^{46,47)}$ and similarly $\mathrm{Mg}_{3} \mathrm{~N}_{2}$ can be hydrogenated into $2 \mathrm{MgH}_{2}$ and $\mathrm{Mg}\left(\mathrm{NH}_{2}\right)_{2} \cdot{ }^{49)}$ If these reactions proceed as well, the phases of $\mathrm{MgH}_{2}$ and/or $\mathrm{LiNH}_{2}$ might appear in addition with the phases of $\mathrm{LiH}$ and $\mathrm{Mg}\left(\mathrm{NH}_{2}\right)_{2}$ after the hydrogenation has been performed. However the above reactions do not proceed in this work. Therefore, if there are some elementary solid-gas reactions mediated by ammonia even in the hydrogenation reaction, the hydrogenation reaction can be understood as well. Currently, the mechanism of hydrogenation for this system is under investigation. In addition, preliminary results indicated that the $\mathrm{H}_{2}$ release pressure in the $\mathrm{HD}$ reaction is higher than $5 \mathrm{MPa}$ at $200^{\circ} \mathrm{C}$.

In conclusion, the above experimental results indicate that the novel metal-N-H system composed of $3 \mathrm{Mg}\left(\mathrm{NH}_{2}\right)_{2}$ and $8 \mathrm{LiH}$ prepared by ball milling is one of the promising candidates for $\mathrm{H}$-storage. ${ }^{48)}$

\section{Hydrogen Storage Properties of Graphite Based Materials}

Generally, hydrogen is adsorbed in carbon based materials on chemisorption and physisorption. Chemisorbed hydrogen is strongly bound with large adsorption heat of $2 \sim 3 \mathrm{eV}$ and requires high temperatures more than $300^{\circ} \mathrm{C}$ to be released, while physisorbed hydrogen is more weakly bound with small adsorption heat of $\sim 0.1 \mathrm{eV}$, which has been considered to be suitable for H-storage at room temperature.

Since the discovery of new carbon materials such as carbon nanotubes, fullerenes, nanofibers and so on, much attention has been paid on hydrogen adsorption on/in new carbon systems for H-storage. ${ }^{50-64)}$ In 1997, Dillon et al. reported that single walled carbon nanotube $(\mathrm{SWNT})^{50)}$ could store up to $5 \sim 10$ mass $\%$ of hydrogen by physisorption under a $\mathrm{H}_{2}$ gas pressure of $0.05 \mathrm{MPa}$ and at room temperature by opening the caps of SWNT. After that, many researchers have performed similar experiments on SWNT, but their data on H-storage capacity at room temperature have widely scattered from 0 to 7 mass $\%$. Therefore, how much hydrogen absorbs in SWNT is still an unsettled issue till now. In 1998, Chembers et al. claimed that the Herringbone-type carbon nanofiber could adsorb up to 67 mass $\%$ of hydrogen by physisorption at room temperature and reversibly adsorbed/ desorbed $\sim 70 \%$ of the adsorbed hydrogen at room temper- 
ature. $^{51)}$ These data have not been reproduced yet as well. So, it is impossible to draw definitive conclusions on the prospects for $\mathrm{H}$-storage on new carbon materials at present. The usage of carbon materials for $\mathrm{H}$-storage seems to be significant potential, but the path to reach the goal still requires a considerable amount of research works.

Motivated by the above reports, our group have studied the $\mathrm{H}$-storage properties of nonstructural graphite prepared by ball milling for $1 \sim 80 \mathrm{~h}$ under hydrogen atmosphere of $1 \mathrm{MPa}$ using $\mathrm{Cr}$ steel pot and balls so far. ${ }^{52-56)}$ The results obtained are summarized as follows: A large amount of hydrogen is chemisorbed up to 7.4 mass $\%$ after milling for $80 \mathrm{~h}$. The chemisorbed hydrogen seems to occupy two different types of the atomic sites, which has been clarified by the neutron diffraction experiments ${ }^{55}$ and $\mathrm{H}^{1}$ NMR measurements. ${ }^{54)}$ One is the $\mathrm{C}-\mathrm{D}(\mathrm{H})$ covalent bonding site located at the edges of the graphite sheets and the other is the defective sites located in between the graphite layers. ${ }^{55)}$ The two $\mathrm{H}_{2}$ desorption peaks are observed at 450 and $720^{\circ} \mathrm{C}$ in the TDMS profile as shown in Fig. 9; the former is due to the desorbed hydrogen from the defective sites, and the later is from the covalent bonding sites. The XRD profiles from the ball milled graphite before and after heating up to $900^{\circ} \mathrm{C}$ are shown in Fig. 9. We notice that nano-structured graphite is formed by ball milling for $80 \mathrm{~h}$ under $\mathrm{H}_{2}$ gas atmosphere of $1 \mathrm{MPa}$ (confirmed by neutron diffraction studies), while the (002) peak grows up after heating up to $900^{\circ} \mathrm{C}$, indicating recovery of a long-range crystallization of graphite interlayer along the c-axis, and the peaks indexed by $\mathrm{Fe}_{3} \mathrm{C}$ grow up after heating up to $900^{\circ} \mathrm{C}$, indicating $1 \sim 2$ at $\%$ of $\mathrm{Fe}$ contamination from the $\mathrm{Cr}$ steel pot and balls after milling for $80 \mathrm{~h}$.
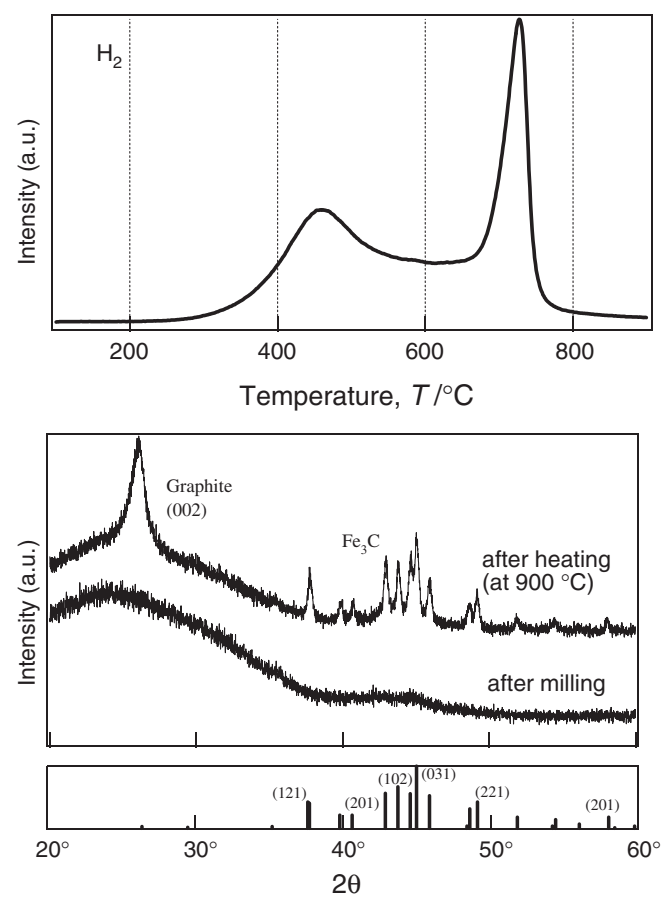

Fig. 9 TDS profiles of nanostructural graphite prepared by mechanically milling in $\mathrm{Cr}$ steel pot and balls without any extra catalysts under hydrogen atmosphere for $80 \mathrm{~h}$ and XRD (after milling and after heating) profiles of corresponding nanostructural graphite before and after heat treatment up to $900^{\circ} \mathrm{C}$, and the indexations are given for $\mathrm{Fe}_{3} \mathrm{C}$.
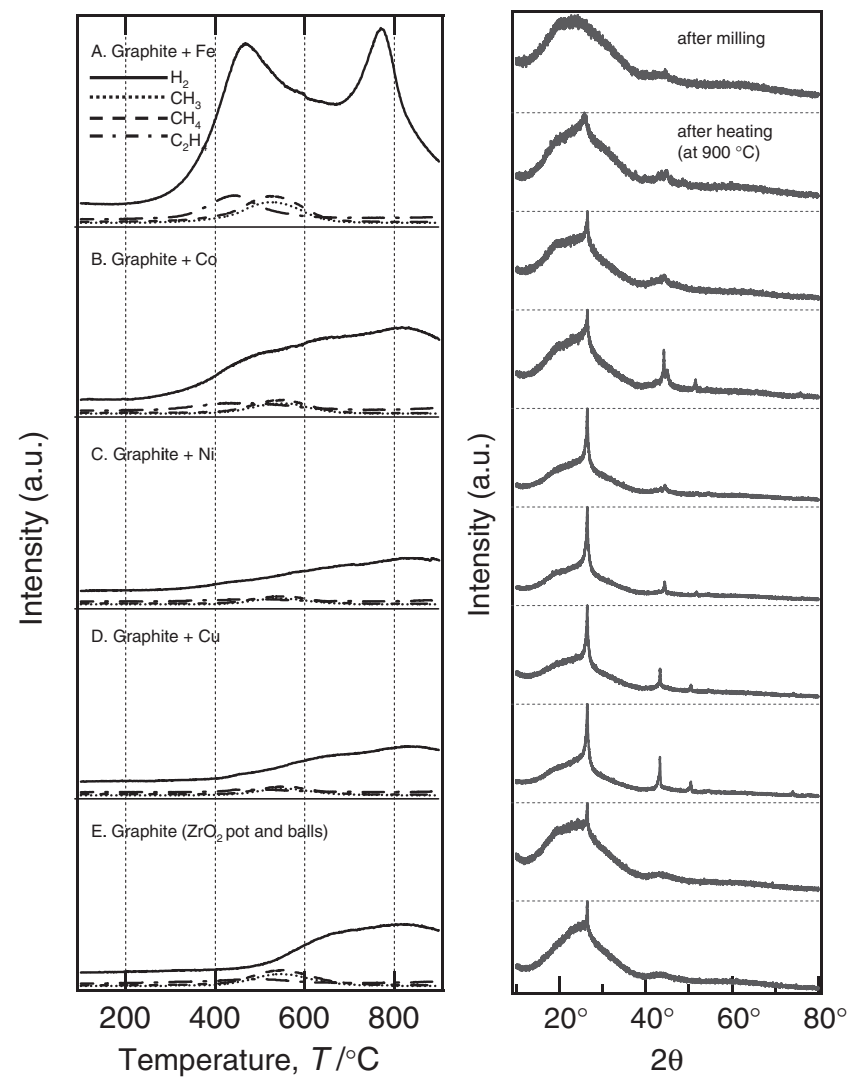

Fig. 10 XRD (after milling and after heating) and TDS profiles $\left(\mathrm{H}_{2}, \mathrm{CH}_{3}\right.$, $\mathrm{CH}_{4}$, and $\mathrm{C}_{2} \mathrm{H}_{4}$ traces) of the samples $\mathrm{A} \sim \mathrm{E}$ after milling for 32 hours.

\subsection{Catalytic effect of 3d-transition metals on hydrogen storage properties}

To clarify whether the contaminated iron acts as a catalyst for $\mathrm{H}$-storage in ball milled graphite, we studied the doping effects of 3d-transition metals on H-storage properties. ${ }^{65,66)}$ Nano-particle metals $\mathrm{Fe}, \mathrm{Co}, \mathrm{Ni}$ and $\mathrm{Cu}$ were used as dopants in this work. In Fig. 10, the TDMS profiles of some graphite catalyzed by $\mathrm{Fe}^{\text {nano }}, \mathrm{Co}^{\text {nano }}, \mathrm{Ni}^{\text {nano }}$ and $\mathrm{Cu}^{\text {nano }}$ are shown together with the XRD profiles before and after heating at $900^{\circ} \mathrm{C}$, where the these samples were prepared by ball milling the mixture of graphite and a small amount ( $1 \mathrm{at} \%$ ) of $\mathrm{Fe}, \mathrm{Co}, \mathrm{Ni}$ and $\mathrm{Cu}$ with several ten nanometer sizes for $32 \mathrm{~h}$ under a $\mathrm{H}_{2}$ gas pressure of $1 \mathrm{MPa}$, respectively, using $\mathrm{Cr}$ steel pot and balls. It is to be noted that $32 \mathrm{~h}$ milling led to very few $\mathrm{Fe}$ contamination from the $\mathrm{Cr}$ steel pot and balls. The sample E in Fig. 10 was prepared by mechanical milling with $\mathrm{ZrO}_{2}$ balls in $\mathrm{ZrO}_{2}$ pot, in which graphite is hardly contaminated with iron.

As is evident from Fig. 10, the Fe-doped sample revealed the most superior H-storage properties among all the doped samples: The TDMS profile indicates that the desorption has two peaks around 450 and $720^{\circ} \mathrm{C}$, the onset for hydrogen release is $\sim 330^{\circ} \mathrm{C}$, and the amount of desorbed hydrogen reaches up to $\sim 4$ mass $\%$ for $32 \mathrm{~h}$ milling. It is to be noted that the TDMS profile is similar to that obtained in the $\mathrm{Fe}$ contaminated graphite during milling for $80 \mathrm{~h}$ (Fig. 8). On the other hand, the TDMS profile of the Co-doped graphite shows that the absorbed hydrogen concentration reaches up to $\sim 2$ mass $\%$ by mechanical milling for $32 \mathrm{~h}$, and the 
desorption takes only a broad peak around $820^{\circ} \mathrm{C}$, but the onset lowers down to $230^{\circ} \mathrm{C}$. The TDMS profiles of $\mathrm{Ni}$ and $\mathrm{Cu}$ doped graphite are no peak structure, being similar to that of no Fe doping graphite (sample E). This indicates that the $\mathrm{Ni}$ and $\mathrm{Cu}$ doping do not show any improvement for $\mathrm{H}-$ storage. These results suggest that the catalytic effect of iron on H-storage properties correlates with the strongest affinity of iron with carbon (graphite) among the other 3d-transition metals.

Despite of the same milling time $(32 \mathrm{~h})$, the XRD profiles shows different features dependent on the doped samples as shown in the right hand side of Fig. 10. The (002) diffraction peak of hexagonal graphite corresponding to graphitic lamellar structure disappears in the Fe-doped graphite after milling for $32 \mathrm{~h}$ similar to the case in the $\mathrm{Fe}$ contaminated graphite, while the (002) peak remains even after milling in the other $\mathrm{Co}, \mathrm{Ni}, \mathrm{Cu}$-doping and no doping graphite. This indicates that $\mathrm{Fe}$ contamination during milling brings a lot of defective sites between the graphene sheets and covalent bonding sites, leading to structure-less (nano-structured) broad profile in the XRD pattern, where a large amount of hydrogen is adsorbed.

From the above results, we conclude that nano-particle iron uniformly dispersed on graphite (confirmed by TEM observation) acts as the most superior catalyst for H-storage, where hydrogen is absorbed up to $\sim 7$ mass $\%$ for $80 \mathrm{~h}$ milling under a $\mathrm{H}_{2}$ atmosphere of $1 \mathrm{MPa}$ and the $\mathrm{H}_{2}$ desorption forms a characteristic two-peak structure around 450 and $720^{\circ} \mathrm{C}$. However, the desorption temperature of chemisorbed hydrogen in nano-structured graphite is still too high for $\mathrm{H}$-storage. Therefore, some break-through is necessary for developing graphite as one of the carbon based H-storage materials.

\subsection{Milling $\mathbf{H}_{2}$-gas pressure effect on hydrogen storage properties}

In the above experiment, we noticed that the inner pressure of hydrogen gas in milling pot lowered down to $0.05 \mathrm{MPa}$ from $1 \mathrm{MPa}$ after milling for $80 \mathrm{~h}$ in the closed system because of the hydrogen adsorption in graphite. Then, we studied $\mathrm{H}$-storage properties of mechanically milled graphite under some hydrogen pressures up to $6 \mathrm{MPa}$ in order to know whether the intrinsic H-storage properties of graphite are improved or not by increasing the milling hydrogen pressure up to $6 \mathrm{MPa}{ }^{66,67)}$

In Fig. 11, the TDMS profiles of hydrogen are shown for mechanically milled graphite at a frequency of $10 \mathrm{~Hz}$ for $80 \mathrm{~h}$ under various $\mathrm{H}_{2}$-gas pressures by a vibrating ball mill equipment, together with that for graphite milled at $400 \mathrm{rpm}$ for $80 \mathrm{~h}$ under a $\mathrm{H}_{2}$-gas pressure of $1 \mathrm{MPa}$ by a planetary ball mill method as well. We can see a common two-peak structure in all kinds of the Fe contaminated graphite. As already described above, the low temperature peak is assigned to the desorption of hydrogen trapped at some defective sites, while the high-temperature one to that of those trapped at the edges of grapheme sheets. As is evident from Fig. 11, the intensity of low temperature peak for nanostructured graphite milled by a vibrating mill method is weaker than that milled by a planetary mill one. On the other hand, the high temperature peak due to hydrogen desorption unexpectedly shifts to higher temperature side with increas-

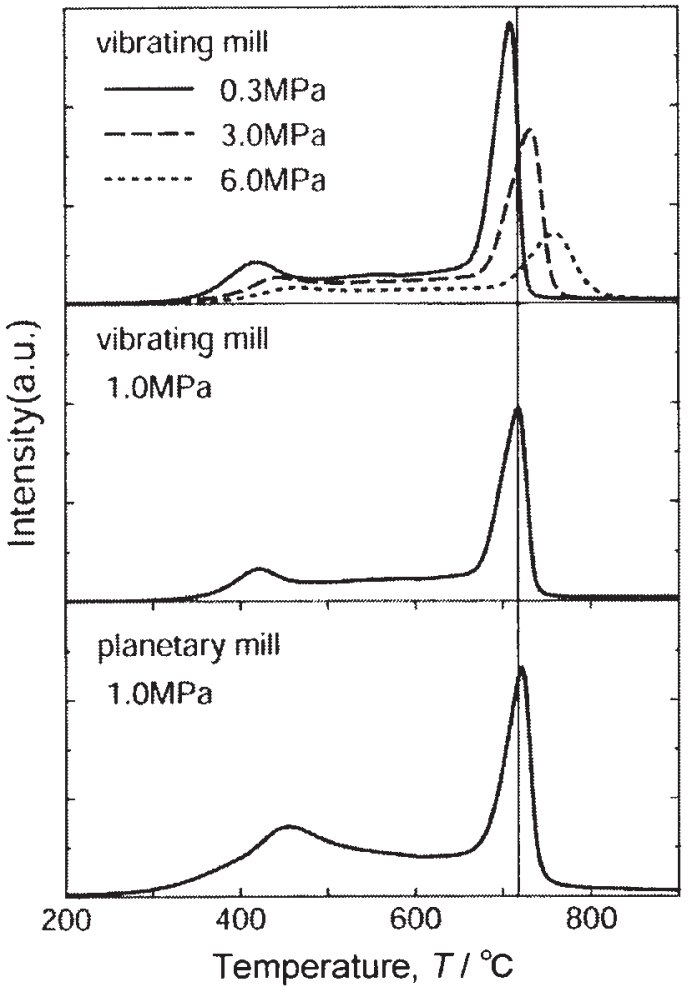

Fig. 11 TDS profiles of mass number $2\left(\mathrm{H}_{2}\right.$-gas) for the nanostructural graphite prepared by vibrating milling for $80 \mathrm{~h}$ under various hydrogen pressures; 0.3, 1.0, 3.0, 6.0 MPa and by planetary milling for $80 \mathrm{~h}$ under $1.0 \mathrm{MPa}$.

ing the milling pressure. However, at the same initial pressure, the position of high temperature peak due to the rotating mill process is almost the same as in the vibrating process, irrespective of the milling type. The structural properties were examined by the XRD measurements. Figure 12 shows the XRD profiles of graphite milled for $2 \mathrm{~h}$ under various hydrogen gas pressures. The intensity of the main (002) peak increases with increasing the milling pressure, indicating that it is hard to make the defects in graphite by milling under higher hydrogen pressure. Actually, we obtained the result that the hydrogen absorption capacity determined by the oxygen combustion hydrogen analysis (OCHA) decreased with increasing the milling pressure. Those unusual results indicate that higher milling pressure of hydrogen leads to further decrease in the chemisorbed hydrogen content and further stability on the occupied sites, which are strongly related with the number of defective sites in the nano-structured graphite.

\subsection{Appearance of physisorption-like hydrogen in graphite milled under high $\mathbf{H}_{2}$-gas pressures}

Hydrogen concentrations determined by a volumetric method and by an OCHA method are compared in Table 1 for the ball milled graphite under various hydrogen gas pressures for $80 \mathrm{~h}$. As is well known, total amount of both chemisorbed and physisorbed hydrogen were estimated from the pressure change in milling pot before and after milling by a volumetric method, while only the chemisorbed hydrogen could be determined by the OCHA method. Therefore, the difference between both of them gives the physisorbed 


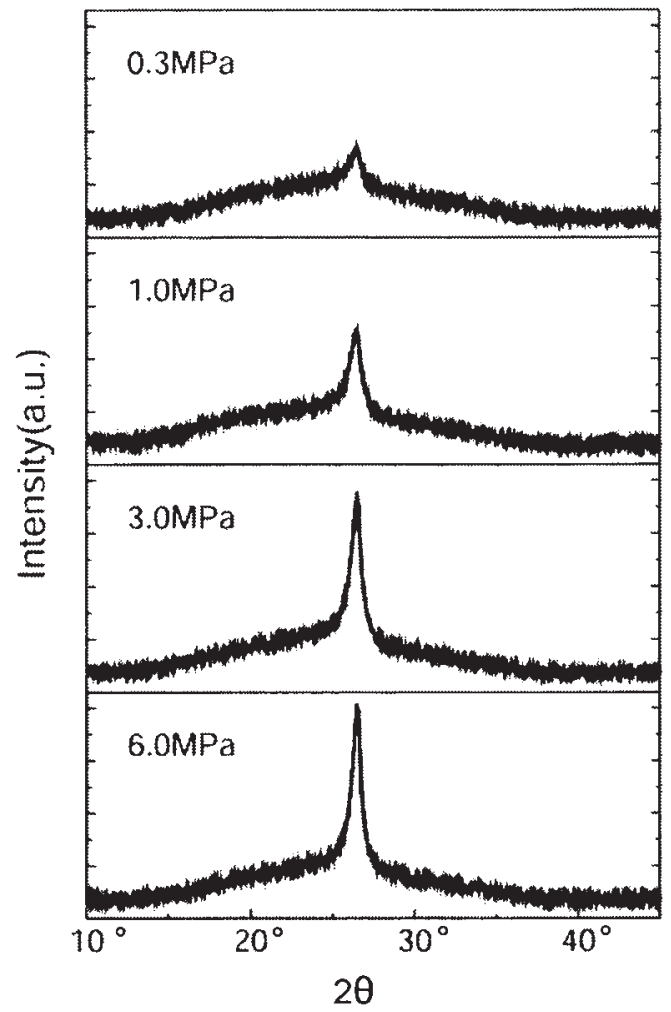

Fig. 12 XRD profiles of the nanostructural graphite milled for $2 \mathrm{~h}$ by vibrating type mill equipment under various hydrogen pressure atmosphere.

Table 1 List of estimated $\mathrm{H}_{2}$ concentration on each $\mathrm{H}_{2}$ pressure by volumetric and OCHA methods.

\begin{tabular}{ccc}
\hline $\begin{array}{c}\mathrm{H}_{2} \\
\text { Pressure }\end{array}$ & $\begin{array}{c}\mathrm{H}_{2} \text { Concentration } \\
\text { (volumetric method) }\end{array}$ & $\begin{array}{c}\mathrm{H}_{2} \text { Concentration } \\
\text { (OCHA method) }\end{array}$ \\
\hline $6.0 \mathrm{MPa}$ & $6.1 \mathrm{mass} \%$ & $6.1 \mathrm{mass} \%$ \\
\hline $3.0 \mathrm{MPa}$ & 5.9 mass $\%$ & 5.7 mass\% \\
\hline $1.0 \mathrm{MPa}$ & 5.7 mass $\%$ & 4.5 mass $\%$ \\
\hline $0.3 \mathrm{MPa}$ & 5.1 mass $\%$ & 4.1 mass $\%$ \\
\hline
\end{tabular}

hydrogen capacity in high-pressure milled graphite. As is seen in the Table 1, we notice that the difference i.e., physisorbed hydrogen concentration, increases with increasing the milling pressure. To clarify how much hydrogen is absorbed in graphite during milling under high pressures of hydrogen gas, the following experiments were performed. (i) Hydrogen gas of $6 \mathrm{MPa}$ was exactly filled in the milling pot with graphite before and after milling and kept at $25.0 \pm$ $0.1^{\circ} \mathrm{C}$. (ii) Then, the valve connecting the milling pot and the reservoir cell was closed, and only the reservoir was degassed below $3 \times 10^{-4} \mathrm{~Pa}$. (iii) Finally, after the valve was opened, the equilibrium pressures in the system were determined for graphite milled under $\mathrm{H}_{2}$-gas pressures of $0.3,1.0,3.0$ and 6.0 MPa. The results obtained are given in Table 2. Here, the physisorption-like hydrogen capacity was evaluated from the difference between the equilibrium pressures before and after milling under various $\mathrm{H}_{2}$ gas pressures. We notice that a considerable physisorbed hydrogen of $0.5 \sim 1.0$ mass $\%$ is only observed in graphite after milling under higher pressures than $3 \mathrm{MPa}$ of $\mathrm{H}_{2}$-gas.
Table 2 List of pressure value, the gas kind during milling process by vibrating mill, equilibrium hydrogen pressure and estimated unstable $\mathrm{H}_{2}$ concentration.

\begin{tabular}{lccc}
\hline Pressure & $\begin{array}{c}\text { Atmospheric } \\
\text { Gas }\end{array}$ & $\begin{array}{c}\text { Equilibrium } \\
\mathrm{H}_{2} \text { pressure }\end{array}$ & $\begin{array}{c}\text { Concentration } \\
\text { (unstable } \mathrm{H}_{2} \text { ) }\end{array}$ \\
\hline Milling sample (after milling for $80 \mathrm{~h}$ ) & \\
\hline $6.0 \mathrm{MPa}$ & $\mathrm{H}_{2}$ & $0.882 \mathrm{MPa}$ & $>0.5$ mass $\%$ \\
\hline $6.0 \mathrm{MPa}$ & $\mathrm{Ar}$ & $0.870 \mathrm{MPa}$ & 0.0 mass\% \\
\hline $3.0 \mathrm{MPa}$ & $\mathrm{H}_{2}$ & $0.882 \mathrm{MPa}$ & $\sim 0.5$ mass\% \\
\hline $1.0 \mathrm{MPa}$ & $\mathrm{H}_{2}$ & $0.868 \mathrm{MPa}$ & 0.0 mass \\
\hline $0.3 \mathrm{MPa}$ & $\mathrm{H}_{2}$ & $0.868 \mathrm{MPa}$ & 0.0 mass $\%$ \\
\hline Host (before milling) & & \\
\hline
\end{tabular}

From the above results, we conclude that the amount of chemisorbed hydrogen decreased with increasing the milling pressure, while physisorption-like hydrogen appeared the milling pressure above $3 \mathrm{MPa}$, the amount of which increased with increasing the milling pressure. On the other hand, the higher milling pressure gave suppression of the fracture rate of graphite structure more effectively, suggesting that the hydrogen atoms trapped at the edges of the graphene sheets and between the graphene sheets near the surface are responsible for preserving the lamellar structure of nanometer scale, which may be the host for $\mathrm{H}$-storage on physisorption. ${ }^{66,67)}$

\section{Hydrogen Storage Properties of Magnesium Based Materials}

Magnesium hydride $\left(\mathrm{MgH}_{2}\right)$ is one of the attractive $\mathrm{H}$ storage materials because it is directly formed from the reaction of bulk $\mathrm{Mg}$ with gaseous hydrogen and reaches up to high hydrogen capacity (7.6 mass\%). However, the reaction is too slow for practical use and needs higher temperature than $300^{\circ} \mathrm{C}$ for progressing the HD reaction. ${ }^{68-70)}$

Recently, the nano-structured $\mathrm{Mg}$ or $\mathrm{MgH}_{2}$ prepared by a mechanical milling method has been studied to improve the reaction kinetics without reducing its high hydrogen capacity. ${ }^{71-73)}$ Furthermore, the H-storage properties of some catalyzed $\mathrm{Mg}$ or $\mathrm{MgH}_{2}$ by a small amount of transition metals $\mathrm{Ti}, \mathrm{V}, \mathrm{Mn}, \mathrm{Fe}, \mathrm{Co}, \mathrm{Ni}, \mathrm{Cu}$ and $\mathrm{Pd}$ or transition metal oxides has been studied so far. ${ }^{73-83)}$ Liang et al. have reported some good $\mathrm{H}$-storage properties of ball milled $\mathrm{MgH}_{2}$ with 5 at\% transition metals (Ti, V, Mn, Fe and Ni). ${ }^{74-78)}$ Zaluska et al. have studied $\mathrm{H}$-storage properties of $\mathrm{Mg}$ composites prepared by ball milling with 1 mass \% transition metals (Pd and $\mathrm{Fe}$ ), in which $\sim 5$ mass $\%$ of hydrogen was absorbed at $300^{\circ} \mathrm{C}$ within ten minutes under a $\mathrm{H}_{2}$-gas pressure of $1 \mathrm{MPa}{ }^{73)}$ They observed that the catalyst was uniformly distributed on the magnesium surface in the form of nanoparticles. This indicates that when very small (of the size of several tens nanometers) particles of the catalyst is uniformly distributed on the metal surface, a small amount of catalysts is sufficient for improving the reaction kinetics. Recently, Kanoya et al. have investigated $\mathrm{H}$-storage properties of some ball milled $\mathrm{Mg}$ with a small amount of nano-sized metals (Ni and $\mathrm{Fe}$ ) as a catalyst. ${ }^{79)}$ Their results indicated that $\mathrm{Mg}$ - 
$0.33 \mathrm{Ni}-0.17 \mathrm{Fe}$ (at.\%) absorbed 7.49 mass $\%$ of hydrogen at $300^{\circ} \mathrm{C}$ by ball milling for only $15 \mathrm{~min}$. Oelerich et al. have reported some good catalytic effect of the transition metal oxide for $\mathrm{MgH}_{2} \cdot{ }^{80-83)}$ The composites prepared by ball milling for $100 \mathrm{~h}$ with $0.2 \mathrm{~mol} \% \mathrm{Nb}_{2} \mathrm{O}_{5}$ absorbed 7 mass $\%$ of hydrogen within $60 \mathrm{~s}$ and desorbed within $130 \mathrm{~s}$ at $300^{\circ} \mathrm{C}{ }^{83)}$

In our group, it has been reported that Pd-coated nanostructured $\mathrm{Mg}$ films prepared by a RF sputtering method absorb $\sim 5$ mass $\%$ at $100^{\circ} \mathrm{C}$ under hydrogen atmosphere of $0.1 \mathrm{MPa}$ and completely desorb below $100^{\circ} \mathrm{C}$ in vacuum. This confirms that $\mathrm{MgH}_{2}$ is applicable for practical use if we can modify bulk $\mathrm{MgH}_{2}$ into suitable nano-structure. ${ }^{84,85)}$ Prior to the studies of catalytic effect on $\mathrm{H}$-storage properties of $\mathrm{MgH}_{2}$, we examined the correlation between H-storage properties and structural characteristics in mechanically milled magnesium hydride $\mathrm{MgH}_{2}$ itself. ${ }^{86}$ The results indicated that at the early stage within $2 \mathrm{~h}$ milling, the amount of desorbed hydrogen decreases $\sim 16 \%$ from 7.3 to $6.1 \mathrm{mass} \%$ and the onset temperature of dehydrogenation decreases by $70^{\circ} \mathrm{C}$ from $400^{\circ} \mathrm{C}$, while both the powder size and the crystallite size in powder decrease with increasing the milling time down to $1 \mu \mathrm{m}$ and $15 \mathrm{~nm}$, respectively, and the lattice strain of $0.3 \%$ is rapidly introduced as well.

At the next step of systematic studies of improving $\mathrm{H}$ storage properties in $\mathrm{Mg}$ systems, we studied the catalytic effect of 3d-transition metals $\mathrm{Fe}, \mathrm{Co}, \mathrm{Ni}$, and $\mathrm{Cu}$ and oxide $\mathrm{Nb}_{2} \mathrm{O}_{5}$ on $\mathrm{H}$-storage in $\mathrm{MgH}_{2}$ without exposing to air the products in all the preparing and measuring processes.

\subsection{Catalytic effect of 3d-transition metals on $\mathrm{H}_{2}$ - storage properties in milled $\mathrm{MgH}_{2}$}

We examined the doping effect of nanometer-sized 3dtransition metals, $\mathrm{Fe}, \mathrm{Co}, \mathrm{Ni}$, and $\mathrm{Cu}$ on $\mathrm{H}$-storage properties in $\mathrm{MgH}_{2}$ prepared by mechanically milling method.

Figure 13 shows the TDMS profiles of the $\mathrm{H}_{2}$ gas for pure $\mathrm{MgH}_{2}$ and some catalyzed $\mathrm{MgH}_{2}$ with $1 \mathrm{~mol} \% \mathrm{Fe}, \mathrm{Co}$, Ni and $\mathrm{Cu}$ nanoparticle metals prepared by ball milling for $2 \mathrm{~h}$ under a $\mathrm{H}_{2}$ gas atmosphere of $1 \mathrm{MPa}$. We can see that all the composites with nanoparticle metals as catalyst exhibit better $\mathrm{HD}$ properties than the pure milled $\mathrm{MgH}_{2}$ : The HD temperature is lowered and a larger amount of hydrogen $(\sim 7$ mass $\%)$ are desorbed by introducing a small amount ( $1 \mathrm{~mol} \%$ ) of catalysts. It should be noted that all the catalyzed $\mathrm{MgH}_{2}$ indicated a larger desorbed hydrogen capacity than nocatalyzed $\mathrm{MgH}_{2}$. This may be due to release of excess hydrogen absorbed during milling $\mathrm{MgH}_{2}$ with catalysts under $\mathrm{H}_{2}$-gas atmosphere. The Ni-doped composite shows the best HD properties among all the catalyzed $\mathrm{MgH}_{2}$ composites and the peak temperature $\left(260^{\circ} \mathrm{C}\right)$ is about $100^{\circ} \mathrm{C}$ lower than that of the pure milled $\mathrm{MgH}_{2}$. In addition, it seems likely that these HD properties depend on the states of 3d-electorns because the peak temperature of hydrogen desorption decreases with increasing a number of occupied 3d-electrons on those transition metals except for $\mathrm{Cu}$, which is known as one of non-catalytic materials from the fact that the $3 \mathrm{~d}$ electron shell of $\mathrm{Cu}$ metal is fully occupied. ${ }^{87)}$

Next, we examined how the HD properties in the Ni-doped system are improved by changing the milling time, the milling revolution speed and the amount of $\mathrm{Ni}$ catalyst to optimize the milling conditions for $\mathrm{H}$-storage.

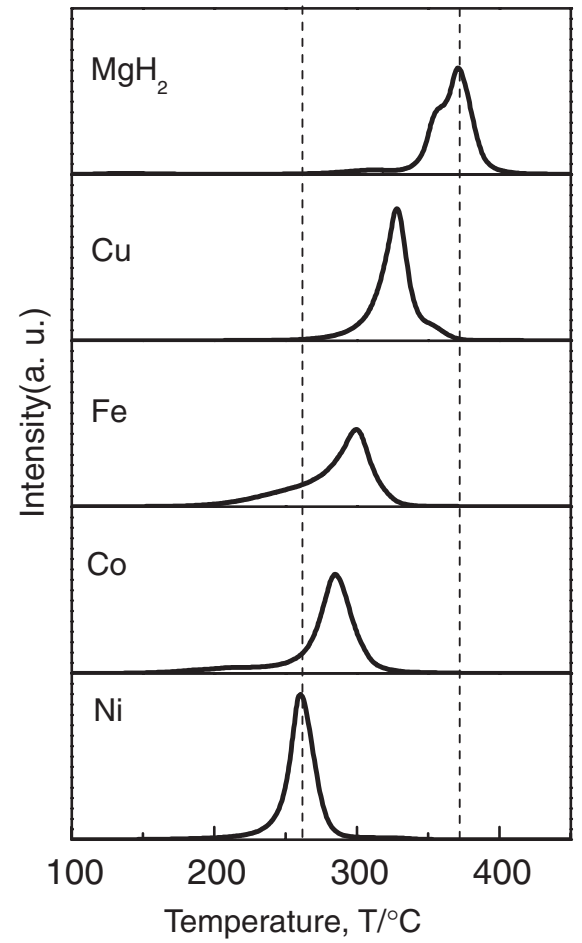

Fig. 13 Thermal desorption mass spectra (TDMS) of hydrogen for pure $\mathrm{MgH}_{2}$ and catalyzed $\mathrm{MgH}_{2}$ by adding a small amount (1 mol\%) of $\mathrm{Cu}, \mathrm{Fe}$ $\mathrm{Co}$ and $\mathrm{Ni}$ nanoparticle metals milled for $2 \mathrm{~h}$.

(1) At the first step, we changed the milling time from $15 \mathrm{~min}$ to $2 \mathrm{~h}$ at $400 \mathrm{rpm}$ for $1 \mathrm{~mol} \% \mathrm{Ni}$-doped $\mathrm{MgH}_{2}$ composite, and examined the TDMS profiles. The results are shown in Fig. 14. We notice that the composite milled for 15 min leads to the onset temperature of $\mathrm{HD}$ reaction about at $\sim 150^{\circ} \mathrm{C}$ and the decrease in the peak temperature to 210 from $260^{\circ} \mathrm{C}$. So, we conclude that the shorter of the milling time brings the better HD properties. However, the HD spectra composed of two broad peaks and distribute in wide temperature range of $150 \sim 300^{\circ} \mathrm{C}$.

(2) At the second step, we changed the milling revolution speed from $400 \mathrm{rpm}$ to $200 \mathrm{rpm}$ under the short milling time of $15 \mathrm{~min}$, and performed the TDMS measurements. In Figs. 15(a) and (b), the TDMS profiles are shown for the $1 \mathrm{~mol} \% \mathrm{Ni}$-doped $\mathrm{MgH}_{2}$ composite milled at $400 \mathrm{rpm}$ and $200 \mathrm{rpm}$, respectively. You can see that the profile of the composite milled at $200 \mathrm{rpm}$ consists in a single HD peak, but the temperature range is still wide from 150 to $300^{\circ} \mathrm{C}$.

(3) Finally, we changed the amount of $\mathrm{Ni}$ nanoparticle catalyst from $1 \mathrm{~mol} \%$ to $2 \mathrm{~mol} \%$ under the same conditions of the short milling time for $15 \mathrm{~min}$ and the slow milling revolution speed at $200 \mathrm{rpm}$, and we performed the TDMS measurements. As is shown in Fig. 15(c), the $\mathrm{MgH}_{2}$ composite with $2 \mathrm{~mol} \% \mathrm{Ni}$ shows the most superior HD profile in the TDMS curves in all the composites examined in this work.

Thus, we found that the $2 \mathrm{~mol} \% \mathrm{Ni}$-doped $\mathrm{MgH}_{2}$ prepared by ball milling under the short milling time for $15 \mathrm{~min}$ and slow milling revolution speed at $200 \mathrm{rpm}$ desorbs a large amount of hydrogen $(\sim 6.5$ mass $\%)$ in the temperature from 150 to $250^{\circ} \mathrm{C}$ at the heating rate of $5^{\circ} \mathrm{C} / \mathrm{min}$. From these results, we conclude that the short milling time and slow 


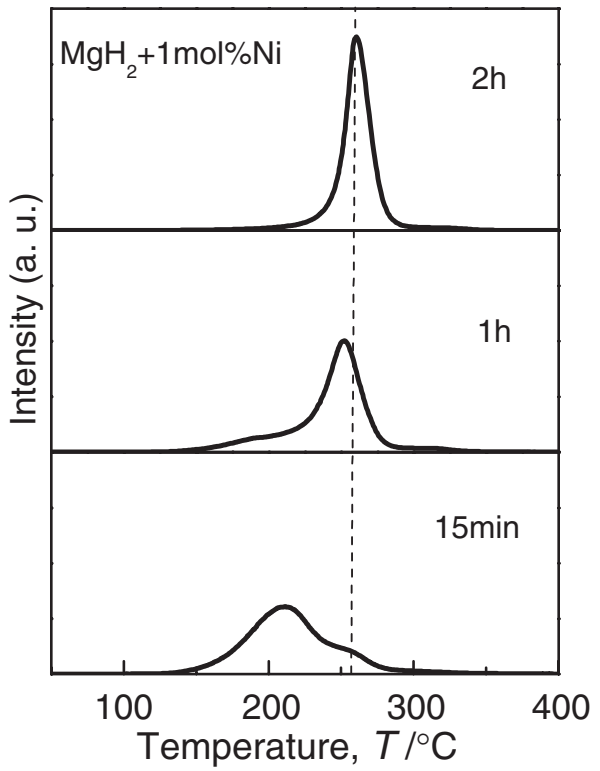

Fig. 14 TDMS profiles of hydrogen from the $\mathrm{MgH}_{2}$ composite catalyzed by $1 \mathrm{~mol} \% \mathrm{Ni}$ in the milling conditions for $15 \mathrm{~min}, 1 \mathrm{~h}$, and $2 \mathrm{~h}$ at $200 \mathrm{rpm}$ under a $\mathrm{H}_{2}$ gas atmosphere of $1 \mathrm{MPa}$.

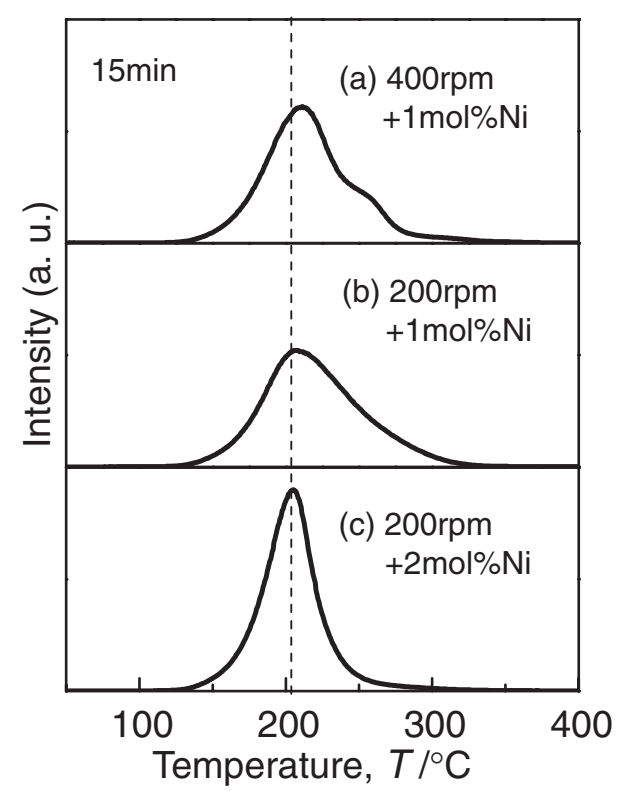

Fig. 15 TDMS profiles of hydrogen for the products milled $\mathrm{MgH}_{2}$ for $15 \mathrm{~min}$ (a) at $400 \mathrm{rpm}$ with $1 \mathrm{~mol} \% \mathrm{Ni}$, (b) at $200 \mathrm{rpm}$ with $1 \mathrm{~mol} \% \mathrm{Ni}$, and (c) at $200 \mathrm{rpm}$ with $2 \mathrm{~mol} \% \mathrm{Ni}$, respectively.

milling revolution speed brings the better HD properties for the $\mathrm{MgH}_{2}+2 \mathrm{~mol} \%$ Ni composite. To clarify the reason why the HD properties for $\mathrm{MgH}_{2}$ are so improved by a small amount of $\mathrm{Ni}$ catalyst, we examined the observation of morphology of the $2 \mathrm{~mol} \% \mathrm{Ni}$-doped $\mathrm{MgH}_{2}$ composite. In Fig. 16, the EDX micrographs corresponding to the $\mathrm{Mg}$ and $\mathrm{Ni}$ element distribution are shown for $\mathrm{MgH}_{2}+2 \mathrm{~mol} \% \mathrm{Ni}$ composite milled for $15 \mathrm{~min}$ at $200 \mathrm{rpm}$. We can see that the nanoparticle $\mathrm{Ni}$ uniformly disperses on the surface of the $\mathrm{MgH}_{2}$ particles by ball milling for such a short time and under such a slow milling revolution speed. When the micron meter sized $\mathrm{Ni}$ was used as a catalyst in $\mathrm{MgH}_{2}$ in the milling
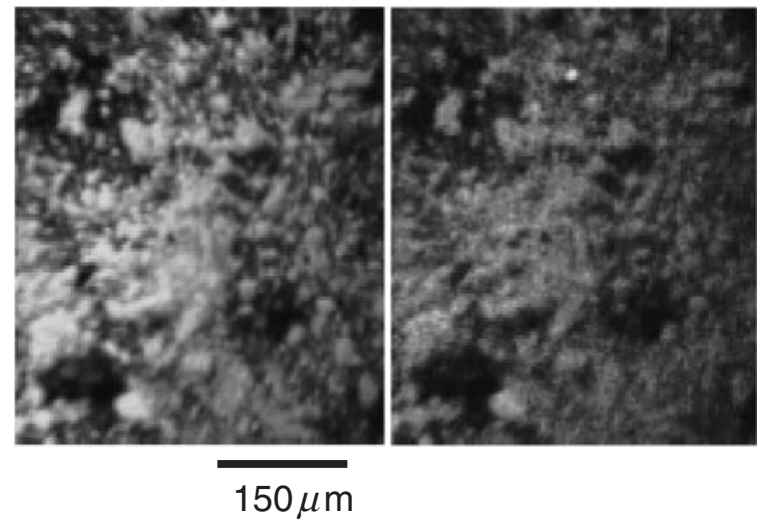

Fig. 16 EDX micrographs of (a) $\mathrm{Mg}$ and (b) Ni elements in the catalyzed $\mathrm{MgH}_{2}$ composite by $2 \mathrm{~mol} \%$ Ni prepared by milling for $15 \mathrm{~min}$ at $200 \mathrm{rpm}$.

process, we could not find out such superior H-storage properties.

Next, we examined the reversible properties of hydriding/ dehydriding reactions for the sample of $\mathrm{MgH}_{2}+2 \mathrm{~mol} \% \mathrm{Ni}$ prepared by milling for $15 \mathrm{~min}$ at $200 \mathrm{rpm}$ under $\mathrm{H}_{2}$ gas atmosphere of $1 \mathrm{MPa}$. The reversibility was tested by the following cyclic processes: the dehydrogenation was performed by holding the sample at $150^{\circ} \mathrm{C}$ (corresponding to the onset temperature for dehydrogenation) and at $200^{\circ} \mathrm{C}$ (corresponding to the peak temperature for dehydrogenation) for $12 \mathrm{~h}$ under high vacuum, and then the hydrogenation was performed under pure hydrogen gas up to $3 \mathrm{MPa}$ at 150 and $200^{\circ} \mathrm{C}$ for $12 \mathrm{~h}$, respectively. After completing those hydrogen absorbing/desorbing cycles, we examined the HD properties by the TGA and TDMS measurement. The results obtained are shown in Fig. 17. The dehydrogenation properties after $2 \mathrm{nd}$ cycle at $150^{\circ} \mathrm{C}$ is better than that after $2 \mathrm{nd}$ cycle at $200^{\circ} \mathrm{C}$, but is slightly worse than that after 1 st cycle after

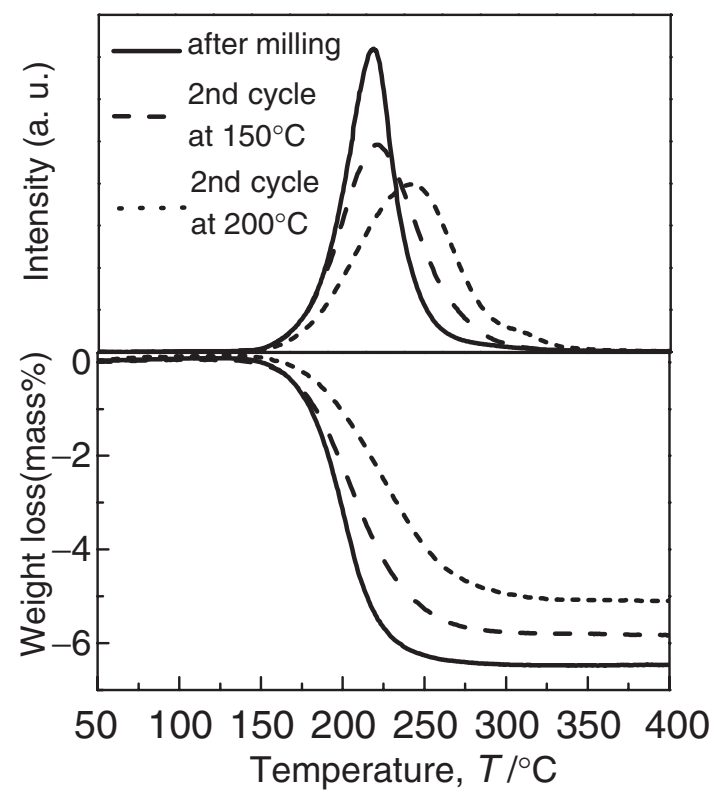

Fig. 17 TDMS profiles of hydrogen for the $2 \mathrm{~mol} \% \mathrm{Ni}$ catalyzed $\mathrm{MgH}_{2}$ composite prepared by milling for $15 \mathrm{~min}$ at $200 \mathrm{rpm}$. The solid, dashed and dotted lines are corresponding to the product after milling for $15 \mathrm{~min}$ at $200 \mathrm{rpm}$, the sample after the 2nd hydriding/dehydriding cycle at $150^{\circ} \mathrm{C}$ and the sample after 2 nd cycle at $200^{\circ} \mathrm{C}$, respectively. 


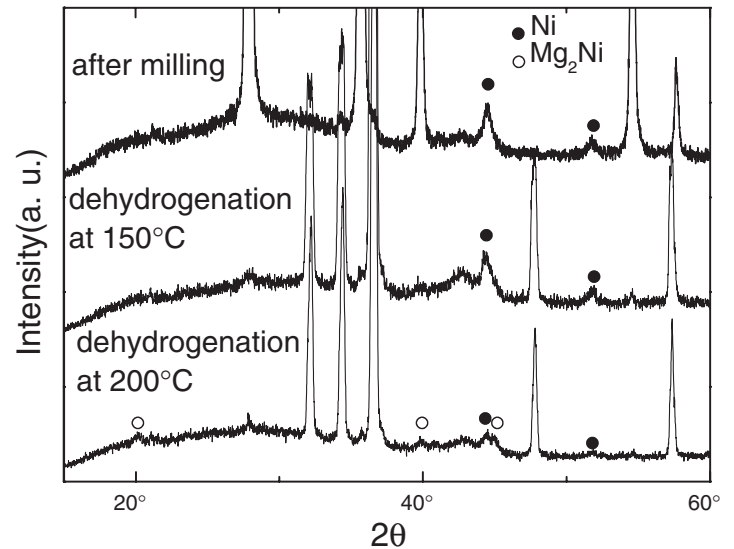

Fig. $18 \mathrm{X}$-ray diffraction profiles for the $2 \mathrm{~mol} \% \mathrm{Ni}$-catalyzed $\mathrm{MgH}_{2}$ composite prepared after milling for $15 \mathrm{~min}$ at $200 \mathrm{rpm}$, the product after dehydrogenation at $150^{\circ} \mathrm{C}$ and the sample after dehydrogenation at $200^{\circ} \mathrm{C}$.

milling. As is seen in Fig. 18, the X-ray diffraction profiles indicate that both of the products after milling and after its dehydrogenating at $150^{\circ} \mathrm{C}$ have a small peak corresponding to only Ni-metal phase in addition to the main peaks for $\mathrm{MgH}_{2}$. But, in the sample after dehydriding at $200^{\circ} \mathrm{C}$, there are the peaks corresponding to not only metal Ni-metal phase but also $\mathrm{Mg}_{2} \mathrm{Ni}$ phase. Since the catalytic effect of $\mathrm{Mg}_{2} \mathrm{Ni}$ is weaker than $\mathrm{Ni}$-metal for improving the $\mathrm{H}$-storage properties, the formation of $\mathrm{Mg}_{2} \mathrm{Ni}$ in the $\mathrm{MgH}_{2}+\mathrm{Ni}$ composite would lead to the worse $\mathrm{H}$-storage properties. This is also the reason why the short milling time and slow milling revolution speed brings the better HD properties for the $\mathrm{MgH}_{2}+2 \mathrm{~mol} \% \mathrm{Ni}$ composite. Because the milling for a long time at high revolution speed easily leads to the $\mathrm{Mg}_{2} \mathrm{Ni}$ phase at the phase boundaries between the nanoparticle $\mathrm{Ni}$ and main $\mathrm{Mg}$ phases due to the strong affinity between $\mathrm{Mg}$ and $\mathrm{Ni}$ atoms.

\subsection{Catalytic effect of metal oxide $\mathrm{Nb}_{2} \mathrm{O}_{5}$ on hydrogen storage properties}

Figure 19 shows the TDMS profiles of $\mathrm{H}_{2}$ for the $\mathrm{MgH}_{2}$ composite with $1 \mathrm{~mol} \% \mathrm{Nb}_{2} \mathrm{O}_{5}$ prepared by ball milling for $15 \mathrm{~min}, 2 \mathrm{~h}$, and $20 \mathrm{~h}$ at $400 \mathrm{rpm}$ under a $\mathrm{H}_{2}$ gas atmosphere of $1 \mathrm{MPa}$. The composite milled for $15 \mathrm{~min}$ has two HD peaks around $230^{\circ} \mathrm{C}$ and $270^{\circ} \mathrm{C}$, which are much lower than that for pure $\mathrm{MgH}_{2}$ milled for $15 \mathrm{~min}\left(370^{\circ} \mathrm{C}\right)$. This indicates that $\mathrm{Nb}_{2} \mathrm{O}_{5}$ is one of the good catalysts for improving the HD properties in $\mathrm{MgH}_{2}$. To optimize the milling condition for improving the HD properties, we increased the milling time up to $20 \mathrm{~h}$ from $15 \mathrm{~min}$ for the $\mathrm{Nb}_{2} \mathrm{O}_{5}$-doped composite. After $2 \mathrm{~h}$ milling, the HD peak at high temperature becomes much weaker as is shown in Fig. 19. Furthermore, the milling for $20 \mathrm{~h}$ leads to single $\mathrm{HD}$ peak around $230^{\circ} \mathrm{C}$, possessing a large amount of hydrogen $(\sim 6.0$ mass $\%)$. This result indicates that the $\mathrm{HD}$ properties of the $\mathrm{Nb}_{2} \mathrm{O}_{5}$-doped composite are much improved with increasing the milling time in contrast to the case of the Ni-catalyzed composite.

As is evident from Fig. 20(a), the composite of $\mathrm{MgH}_{2}$ and $1 \mathrm{~mol} \% \mathrm{Nb}_{2} \mathrm{O}_{5}$ milled for $20 \mathrm{~h}$ shows the existence of $\beta-\mathrm{MgH}_{2}$ and a small amount of $\mathrm{MgO}$ in the XRD profiles, but there is no trace corresponding to the niobium oxide $\mathrm{Nb}_{2} \mathrm{O}_{5}$. This indicates that $\mathrm{Nb}_{2} \mathrm{O}_{5}$ disperses on the surface of $\mathrm{MgH}_{2}$

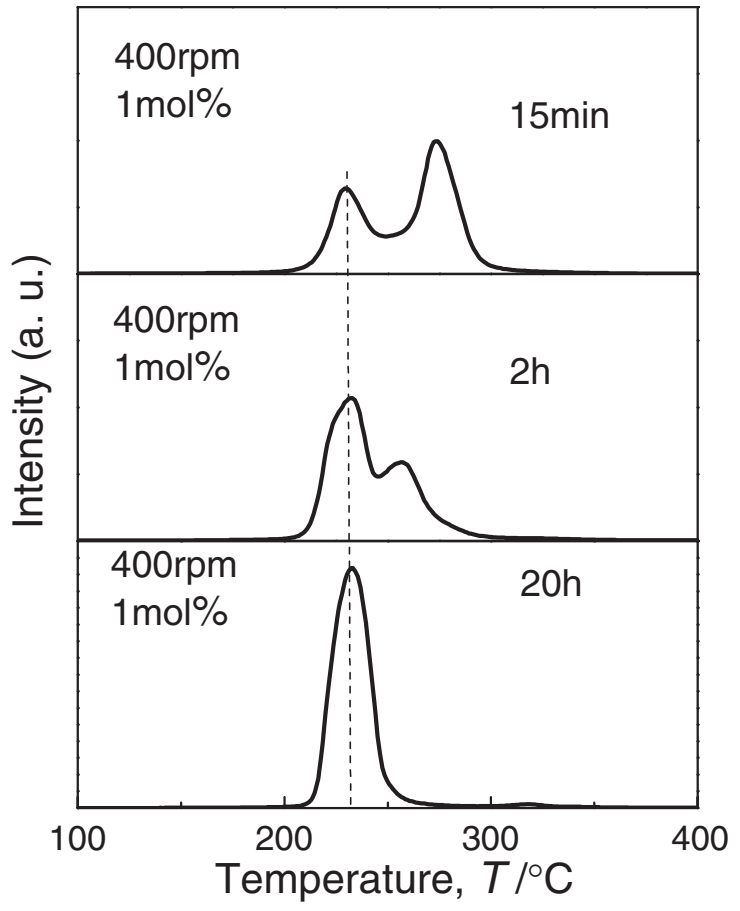

Fig. 19 TDMS profiles of hydrogen from the $\mathrm{MgH}_{2}$ composite with $1 \mathrm{~mol} \% \mathrm{Nb}_{2} \mathrm{O}_{5}$ prepared by milling for $15 \mathrm{~min}, 2 \mathrm{~h}$, and $20 \mathrm{~h}$ at $400 \mathrm{rpm}$ under a $\mathrm{H}_{2}$ gas atmosphere of $1 \mathrm{MPa}$.

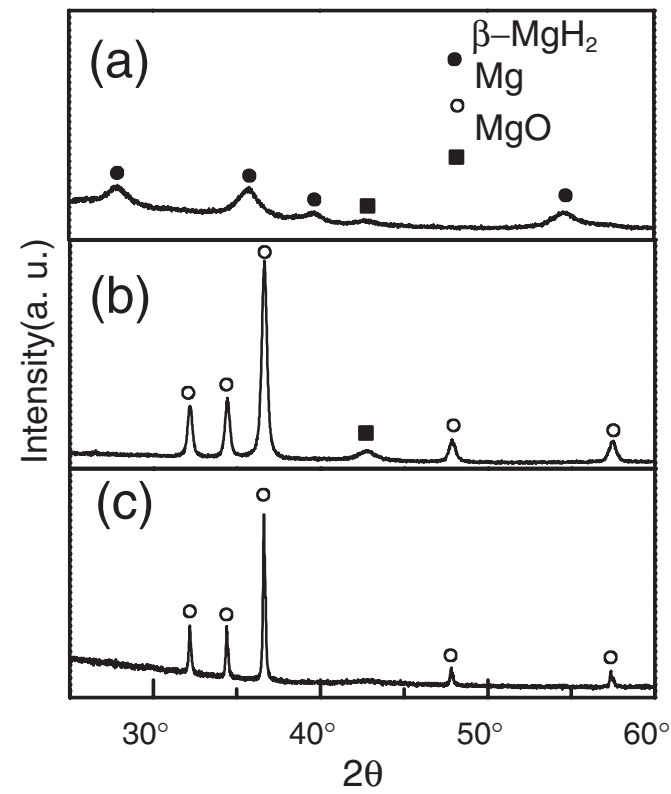

Fig. 20 X-ray diffraction profiles for (a) the $1 \mathrm{~mol} \% \mathrm{Nb}_{2} \mathrm{O}_{5}$-catalyzed $\mathrm{MgH}_{2}$ composite prepared by milling for $20 \mathrm{~h}$, (b) the composite after heat treatment up to $450^{\circ} \mathrm{C}$, (c) the pure $\mathrm{MgH}_{2}$ by milling for $20 \mathrm{~h}$ after heat treatment up to $470^{\circ} \mathrm{C}$.

in the nanometer scale by ball milling and acts as a good catalyst. The XRD profile after heat treatment up to $450^{\circ} \mathrm{C}$ in Fig. 20(b) indicates the existence of $\mathrm{Mg}$ and $\mathrm{MgO}$. In details, the intensity corresponding to the $\mathrm{MgO}$ peak is larger than that in pure $\mathrm{MgH}_{2}$ milled for $20 \mathrm{~h}$ in Fig. 20(c). Therefore, it seems likely that $\mathrm{Nb}_{2} \mathrm{O}_{5}$ dispersed in nanometer scale is reduced by $\mathrm{Mg}$ to form metal $\mathrm{Nb}$ and $\mathrm{MgO}$ during ball milling or heat treatment as follows 


$$
\begin{aligned}
& \frac{1}{2} \mathrm{Nb}_{2} \mathrm{O}_{5}+\frac{5}{2} \mathrm{Mg} \rightarrow \mathrm{Nb}+\frac{5}{2} \mathrm{MgO} \\
& \Delta H=-554.5 \mathrm{~kJ} / \mathrm{mol} \mathrm{Nb} .
\end{aligned}
$$

Since the standard enthalpy change of this reaction is negative and large, this reduction reaction should be possible to proceed during ball milling or heat treatment. Consequently, the metallic $\mathrm{Nb}$ dispersed in nanometer scale could act as an excellent catalyst on hydrogen desorption from $\mathrm{MgH}_{2}$.

Next, we examined the reversible properties of hydriding/ dehydriding reactions at $200^{\circ} \mathrm{C}$ for the composite of $\mathrm{MgH}_{2}$ and $1 \mathrm{~mol} \% \mathrm{Nb}_{2} \mathrm{O}_{5}$ milled for $20 \mathrm{~h}$ according to the same cyclic processes as the $\mathrm{MgH}_{2}$ composite with $\mathrm{Ni}$ nanoparticle. As is shown in Fig. 21, the dehydrogenation property after $2 \mathrm{nd}$ cycle at $200^{\circ} \mathrm{C}$ is better than that after 1st cycle. This suggests that $\mathrm{Nb}_{2} \mathrm{O}_{5}$ is reduced by $\mathrm{Mg}$ to form metallic $\mathrm{Nb}$ during dehydriding/hydriding cycle at $200^{\circ} \mathrm{C}$, leading to the hydrogen desorption of $\sim 6$ mass $\%$ in the temperature range from 150 to $250^{\circ} \mathrm{C}$. This result indicates that $\mathrm{Nb}$ is the best catalyst we have studied so far. Thus, it seems that some magnesium composites catalyzed by $3 \mathrm{~d}$ transition metals nano-particles is acceptable for practical application as a $\mathrm{H}_{2}$ tank for off-board $\mathrm{H}$-storage.

\section{Prospective}

In this paper, we have presented our recent results of $\mathrm{H}-$ storage properties on lithium, graphite and magnesium based materials prepared by some mechanical milling methods. There were some progress on basic materials properties in lithium-N-H and catalyzed magnesium nano-composite systems for H-storage.

Especially, the kinetic properties of the H-storage reactions in $\mathrm{Mg}$ metal were significantly improved by doping a small amount of $\mathrm{Ni}$ metals with several ten nanometers in diameter or $\mathrm{Nb}$ oxides, reaching a level of practical use as a $\mathrm{H}$-storage tank for off-board storage.

In some Li-N-H systems, we found that a large amount of hydrogen (more than 6 mass \%) were reversibly stored in the temperature range from 140 to $200^{\circ} \mathrm{C}$, the temperature of which is still higher than the target of NEDO project or COE

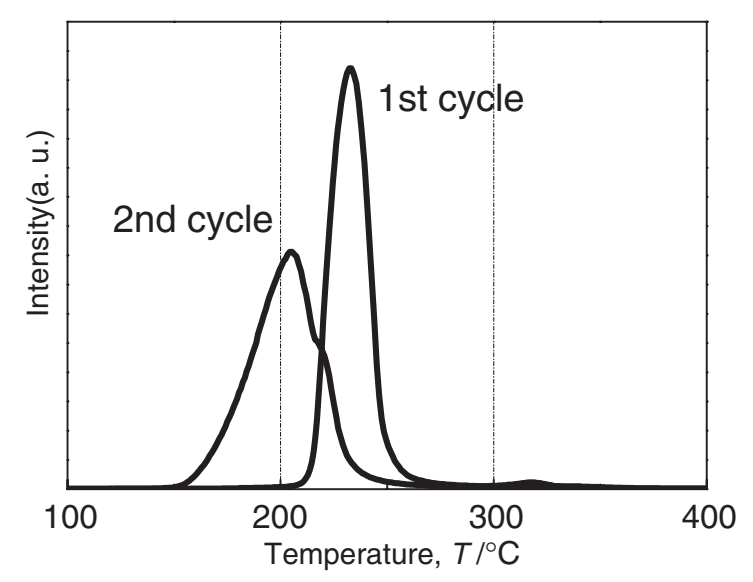

Fig. 21 TDMS profiles of hydrogen for the $1 \mathrm{~mol} \% \mathrm{Nb}_{2} \mathrm{O}_{5}$-catalyzed $\mathrm{MgH}_{2}$ composite prepared by milling for $20 \mathrm{~h}$ (1st cycle) and the sample after 2 nd dehydriding/hydriding cycle at $200^{\circ} \mathrm{C}$ ( 2 nd cycle). target. However, recent quick developments make imagine us that the NEDO target will be cleared in near future in lithium based systems.

On the contrary, we found that the ball milled graphite could make a large amount of hydrogen (more than 7 mass\%) absorbed. However, not only the desorption temperature was not only still too high for $\mathrm{H}$-storage, but also the $\mathrm{H}$-storage reaction was not reversible. Many efforts have been paid on improving $\mathrm{H}$-storage properties in nano-structured graphite prepared by ball milling under hydrogen gas atmosphere, but the properties were still too far from the NEDO target. Therefore, in graphite system, some break-through is necessary to clear the NEDO target. Before proceeding further improving studies, it is important to know whether there is a new, hitherto unknown interaction between carbon and hydrogen whose interaction energy falls between physisorption and chemisorption or not. We believe that the basic studies such as neutron scattering experiments should give us an answer to above question whereby we can solve the carbon controversy concerning how much hydrogen is stored in carbon single wall nano-tube.

As we have mentioned above, currently, in the hydrogen research laboratories all over the world, new approach using non-traditional and nano-technological techniques have been applied to design high-performance $\mathrm{H}$-storage materials. Thus, we believe that, due to this kind of research works, better $\mathrm{H}$-storage materials which absorb and desorb at least 6 mass $\%$ hydrogen at temperatures lower than $150^{\circ} \mathrm{C}$, will be discovered and developed for practical use on board hydrogen tank in near future.

\section{Acknowledgements}

This work was supported by the NEDO project "Development for Safe Utilization and Infrastructure of Hydrogen Industrial Technology" in Japan and the Grant-in-Aid for COE Research (No. 13CE2002) of the Ministry of Education, Culture, Sports, Sciences and Technology of Japan. The authors gratefully acknowledge Miss E. Gomibuchi, Mr. K. Nabeta, Mr. K. Kimura, Mr. S. Hino and Mr. T. Nakagawa for their help in our laboratory.

\section{REFERENCES}

1) G. Sandrock: J. Alloy. Compd. 293-295 (1999) 877-888.

2) E. Akiba: Curr. Opin. Solid. St. M. 4 (1999) 267-272.

3) L. Schlapbach and A. Züttel: Nature 414 (2001) 353-358.

4) P. Vajeeston, P. Ravindran, R. Vidya, H. Fjellvåg and A. Kjekshus: Appl. Phys. Lett. 82 (2003) 2257-2259.

5) W. Grochala and P. P. Edwards: Chem. Rev. 104 (2004) 1283-1315.

6) B. Bogdanović and M. Schwickardi: J. Alloy. Compd. 253 (1997) 1-9.

7) J. Huot, S. Boily, V. Guther and R. Schulz: J. Alloy. Compd. 283 (1999) 304-306.

8) R. A. Zidan, S. Takara, A. G. Hee and C. M. Jensen: J. Alloy. Compd. 285 (1999) 119-122.

9) L. Zaluski, A. Zalsuka and J. O. Ström-Olsen: J. Alloy. Compd. 290 (1999) 71-78.

10) A. Zaluska, L. Zaluski and J. O. Ström-Olsen: J. Alloy. Compd. 298 (2000) 125-134.

11) B. Bogdanović, R. A. Brand, A. Marjanović, M. Schwickardi and J. Tölle: J. Alloy. Compd. 302 (2000) 36-58.

12) J. Chen, N. Kuriyama, Q. Xu, H. T. Takeshita and T. Sakai: J. Phys. Chem. B 105 (2001) 11214-11220. 
13) C. M. Jensen and K. J. Gross: Appl. Phys. A 72 (2001) 213-219.

14) K. J. Gross, G. J. Thomas and C. M. Jensen: J. Alloy. Compd. 330-332 (2002) 683-690.

15) G. Sandrock, K. Gross, G. Thomas, C. Jensen, D. Meeker and S. Takara: J. Alloy. Compd. 330-332 (2002) 696-701.

16) G. P. Meisner, G. G. Tibbetts, F. E. Pinkerton, C. H. Olk and M. P. Balogh: J. Alloy. Compd. 337 (2002) 254-263.

17) G. J. Thomas, K. J. Gross, N. Y. C. Yang and C. Jensen: J. Alloy. Compd. 330-332 (2002) 702-707.

18) G. Sandrock, K. Gross and G. Thomas: J. Alloy. Compd. 339 (2002) 299-308.

19) M. Fichtner and O. Fuhr: J. Alloy. Compd. 345 (2002) 286-296.

20) B. Bogdanovic, M. Felderhoff, M. Germann, M. Hartel, A. Pommerin, F. Schuth, C. Weidenthaler and B. Zibrowius: J. Alloy. Compd. 350 (2003) 246-255.

21) H. Morioka, K. Kakizaki, S. C. Chung and A. Yamada: J. Alloy. Compd. 353 (2003) 310-314.

22) D. L. Anton: J. Alloy. Compd. 356-357 (2003) 400-404.

23) M. Fichtner, O. Fuhr and O. Kircher: J. Alloy. Compd. 356-357 (2003) 418-422.

24) K. J. Gross, E. H. Majzoub and S. W. Spangler: J. Alloy. Compd. 356357 (2003) 423-428.

25) S. M. Opalka and D. L. Anton: J. Alloy. Compd. 356-357 (2003) 486489.

26) P. Vajeeston, P. Ravindran, R. Vidya, H. Fjellvag and A. Kjekshus: Appl. Phys. Lett. 82 (2003) 2257-2259.

27) D. Sun, S. S. Srinivasan, T. Kiyobayashi, N. Kuriyama and C. M. Jensen: J. Phys. Chem. B 107 (2003) 10176-10179.

28) T. Kiyobayashi, S. S. Srinivasan, D. Sun and C. M. Jensen: J. Phys. Chem. A 107 (2003) 7671-7674.

29) M. E. Arroyo y de Dompablo and G. Ceder: J. Alloy. Compd. 364 (2004) 6-12.

30) J. M. Bellosta von Colbe, B. Bogdanović, M. Felderhoff, A. Pommerin and F. Schuth: J. Alloy. Compd. 370 (2004) 104-109.

31) S. C. Chung and H. Morioka: J. Alloy. Compd. 372 (2004) 92-96.

32) D. Sun, S. S. Srinivasan, G. Chen and C. M. Jensen: J. Alloy. Compd. 373 (2004) 265-269.

33) J. Graetz, J. J. Reilly, J. Johnson, A. Yu. Ignatov and T. A. Tyson: Appl. Phys. Lett. 85 (2004) 500-502.

34) O. Kircher and M. Fichtner: J. Appl. Phys. 95 (2004) 7748-7753.

35) H. J. Schlesinger and H. C. Brown: J. Am. Chem. Soc. 62 (1940) 34293435.

36) S. Orimo, Y. Nakamori and A. Züttel: Mater. Sci. Eng. B 108 (2004) 51-53.

37) E. M. Fedneva, V. L. Alpatova and V. I. Mikheeva: Russ. J. Inorg. Chem. 9 (1964) 826-827.

38) A. Züttel, S. Rentsch, P. Fischer, P. Wenger, P. Sudan, Ph. Mauron and Ch. Emmenegger: J. Alloy. Compd. 356-357 (2003) 515-520.

39) F. W. Dafert and R. Miklauz: Monatsh Chem. 31 (1910) 981-996.

40) O. Ruff and H. Goeres: Chem. Ber. 44 (1910) 502-506.

41) P. Chen, Z. Xiong, J. Luo, J. Lin and K. L. Tan: Nature 420 (2002) $302-$ 304.

42) Y. H. Hu and E. Ruckenstein: Ind. Eng. Chem. Res. 42 (2003) 5135 5139.

$43)$ Z. Xiong, P. Chen, G. Wu, J. Lin and K. L. Tan: J. Mater. Chem. 13 (2003) 1676-1680.

44) Y. Nakamori and S. Orimo: J. Alloy. Compd. 370 (2004) 271-275.

45) Y. Nakamori and S. Orimo: Mater. Sci. Eng. B 108 (2004) 48-50.

46) T. Ichikawa, S. Isobe, N. Hanada and H. Fujii: J. Alloy. Compd. 365 (2004) 271-276.

47) T. Ichikawa, N. Hanada, S. Isobe, H. Y. Leng and H. Fujii: J. Phys. Chem. B 108 (2004) 7887-7892.

48) H. Y. Leng, T. Ichikawa, S. Hino, N. Hanada, S. Isobe and H. Fujii: J. Phys. Chem. B 108 (2004) 8763-8765.

49) Y. Nakamori, G. Kitahara, S. Orimo, K. Miwa and S. Towata: 2003 Autumn Meeting of The Japan Institute of Metals, oral presentation.

50) A. C. Dillon, K. M. Jones, T. A. Bekkedahl, C. H. Kiang, D. S. Bethune and M. J. Heben: Nature 386 (1997) 377-379.

51) A. Chambers, C. Park, R. T. K. Baker and N. M. Rodriguez: J. Phys. Chem. B 102 (1998) 4253-4256.

52) S. Orimo, G. Majer, T. Fukunaga, A. Züttel, L. Schlapbach and
H. Fujii: Appl. Phys. Lett. 75 (1999) 3093-3095.

53) S. Orimo, T. Matsushima, H. Fujii, T. Fukunaga and G. Majer: J. Appl. Phys. 90 (2001) 1545-1549.

54) G. Majer, E. Stanik and S. Orimo: J. Alloy. Compd. 356-357 (2003) 617-621.

55) T. Fukunaga, K. Itoh, S. Orimo, M. Aoki and H. Fujii: J. Alloy. Compd. 327 (2001) 224-229.

56) S. Orimo, A. Züttel, L. Schlapbach, G. Majer, T. Fukunaga and H. Fujii: J. Alloy. Compd. 356-357 (2003) 716-719.

57) Y. Ye, C. C. Ahn, C. Witham, B. Fultz, J. Liu, A. G. Rinzler, D. Colbert, K. A. Smith and R. E. Smalley: Appl. Phys. Lett. 74 (1999) 2307.

58) C. Park, P. E. Anderson, A. Chambers, C. D. Tan, R. Hidalgo and N. M. Rodriguez: J. Phys. Chem. B 103 (1999) 10572-10581.

59) C. C. Ahn, Y. Ye, B. V. Ratnakumar, C. Witham, R. C. Bowman, Jr. and B. Fultz: Appl. Phys. Lett. 73 (1998) 3378-3380.

60) L. Schlapbach, A. Züttel, P. Gröning, O. Gröning and P. Aebi: Appl. Phys. A 72 (2001) 245-253.

61) V. Meregalli and M. Parrinello: Appl. Phys. A 72 (2001) 143-146.

62) A. Züttel, Ch. Nützenadel, P. Sudan, Ph. Mauron, Ch. Emmenegger, S. Rentsch, L. Schlapbach, A. Weidenkaff and T. Kiyobayashi: J. Alloy. Compd. 330-332 (2002) 676-682.

63) C. Carpetis and W. Peschka: Int. J. Hydrogen Energy 5 (1980) 539554.

64) K. A. G. Amankwah, J. S. Noh and J. A. Schwarz: Int. J. Hydrogen Energy 14 (1989) 437-447.

65) S. Isobe, T. Ichikawa, J. I. Gottwald, E. Gomibuchi and H. Fujii: J. Phys. Chem. Solids 65 (2004) 535-539.

66) T. Ichikawa, D. M. Chen, S. Isobe, E. Gomibuchi and H. Fujii: Mater. Sci. Eng. B 108 (2004) 138-142.

67) D. M. Chen, T. Ichikawa, H. Fujii, N. Ogita, M. Udagawa, Y. Kitano and E. Tanabe: J. Alloy. Compd. 354 (2003) L5-L9.

68) D. L. Cummings and G. J. Powers: Ind. Eng. Chem. 13 (1974) 182-192.

69) J. F. Stampfer, Jr., C. E. Holley, Jr. and J. F. Suttle: J. Am. Chem. Soc. 82 (1960) 3504-3508.

70) B. Vigeholm, J. Kjoller and B. Larsen: J. Less-Common Met. 74 (1980) 341-350.

71) J. Huot, G. Liang, S. Boily, A. Van Neste and R. Schulz: J. Alloy. Compd. 293-295 (1999) 495-500.

72) F. C. Gennari, F. J. Castro and G. Urretavizcaya: J. Alloy. Compd. 321 (2001) 46-53.

73) A. Zaluska, L. Zaluski and J. O. Ström-Olsen: J. Alloy. Compd. 288 (1999) 217-225.

74) G. Liang, J. Huot, S. Boily, A. Van Neste and R. Schulz: J. Alloy. Compd. 291 (1999) 295-299.

75) G. Liang, J. Huot, S. Boily, A. Van Neste and R. Schulz: J. Alloy. Compd. 292 (1999) 247-252.

76) G. Liang, J. Huot, S. Boily and R. Schulz: J. Alloy. Compd. 305 (2000) 239-245.

77) Z. Dehouche, R. Djaozandry, J. Huot, S. Boily, J. Goyette, T. K. Bose and R. Schulz: J. Alloy. Compd. 305 (2000) 264-271.

78) J. Huot, J. F. Pelletier, G. Liang, M. Sutton and R. Schulz: J. Alloy. Compd. 330-332 (2002) 727-731.

79) I. Kanoya, M. Hosoe and T. Suzuki: Honda R \& D Technical Review 14 (2002) 91.

80) W. Oelerich, T. Klassen and R. Bormann: J. Alloy. Compd. 315 (2001) 237-242.

81) W. Oelerich, T. Klassen and R. Bormann: Adv. Eng. Mater. 3 (2001) 487-490.

82) Z. Dehouche, T. Klassen, W. Oelerich, J. Goyette, T. K. Bose and R. Schulz: J. Alloy. Compd. 347 (2002) 319-323.

83) G. Barkhordarian, T. Klassen and R. Bormann: Scr. Mater. 49 (2003) 213-217.

84) K. Higuchi, K. Yamamoto, H. Kajioka, K. Toiyama, M. Honda, S. Orimo and H. Fujii: J. Alloy. Compd. 330-332 (2002) 526-530.

85) H. Fujii, K. Higuchi, K. Yamamoto, H. Kajioka, S. Orimo and K. Toiyama: Mater. Trans. 43 (2002) 2721-2727.

86) N. Hanada, T. Ichikawa, S. Orimo and H. Fujii: J. Alloy. Compd. 366 (2004) 269-273.

87) J. Harris and S. Andersson: Phys. Rev. Lett. 55 (1985) 1583-1586. 